\title{
NECESSIDADE DE CAPACITAÇÃO DOS PROFISSIONAIS NA EDUCAÇÃO ESPECIAL EM MUNICÍPIO PAULISTA
}

\section{ARTIGO ORIGINAL}

MARCHI, Cynthia Mariana Gonçalves Arroyo ${ }^{1}$

NOZAKI, Maria Eduarda Pontes ${ }^{2}$

MASSARI, Felipe Adolfo K. ${ }^{3}$

HORTA, Maria Fernanda da ${ }^{4}$

ABRAHÃO, Leonardo de Faria Bachelli ${ }^{5}$

RANGEL, Lídia Magalhães ${ }^{6}$

CASTRO, Valéria da Cruz Oliveira de ${ }^{7}$

1 Graduando do $5^{\circ}$ período do curso de Medicina do Centro Universitário de Votuporanga.

2 Graduando do $5^{\circ}$ período do curso de Medicina do Centro Universitário de Votuporanga.

3 Graduando do $5^{\circ}$ período do curso de Medicina do Centro Universitário de Votuporanga.

4 Graduando do $5^{\circ}$ período do curso de Medicina do Centro Universitário de Votuporanga.

5 Graduando do $5^{\circ}$ período do curso de Medicina do Centro Universitário de Votuporanga.

6 Graduando do $5^{\circ}$ período do curso de Medicina do Centro Universitário de Votuporanga.

7 Orientador. Mestre da graduação do curso de Medicina no Centro Universitário de Votuporanga. 
MARCHI, Cynthia Mariana Gonçalves Arroyo. Et al. Necessidade de capacitação dos profissionais na Educação Especial em município paulista. Revista Científica Multidisciplinar Núcleo do Conhecimento. Ano 05, Ed. 11, Vol. 24, pp. 107-43. Novembro de 2020. ISSN: 2448-0959, Link de acesso:https://www.nucleodoconhecimento.com.br/educacao/municipio-paulista

\section{RESUMO}

A Educação Especial em todos os seus âmbitos tem ganhado os holofotes em discussões e pesquisas em todo o país a fim de compreender, analisar ou propor mudanças, visando à formação continuada na Educação Especial, promovendo uma maior atenção ao público em específico. Sendo assim, os discentes do curso de Medicina perceberam uma necessidade de avaliar a aprendizagem dos professores e estagiários no trabalho com crianças que possuem necessidades educacionais especiais em uma escola no interior paulista. Tratou-se, portanto, de uma pesquisa exploratória e descritiva que utilizou variáveis qualitativas e quantitativas que permitem mapear alguns resultados sobre esse processo de socialização e aprendizagem das crianças especiais. Efetivamente, a notória arguição é o reconhecimento das carências educacionais que professores e estagiários encontram no cotidiano com portadores de necessidades especiais. Os resultados evidenciam que há grande esforço didático por parte destes para incluir os alunos com deficiência e estabelecer a integralidade desde a realidade na sala de aula até instrumentos de socialização e desenvolvimento integral da pessoa como um todo. Entretanto, as análises apontam para a importante preocupação dos profissionais da educação que demonstram a acuidade de maior treinamento e reciclagem no âmbito da Educação Especial, aliás, é observado que existe a necessidade de aumentar o tempo de qualificação dos educadores face a complexidade que a tarefa exige.

Palavras-chave: educação especial, educação inclusiva, capacitação de professores, estagiários.

\section{INTRODUÇÃO}


Segundo a Constituição Brasileira (1988), em seu artigo $5^{\circ}$, todos são iguais perante a lei, sendo este direito inviolável. No mesmo documento, o artigo subsequente garante como direito social o acesso à educação. Dessa forma, todos os cidadãos têm assegurado o ensino de forma igualitária. (BRASIL, 1988). A Política Nacional de Atenção Integral à Saúde da Criança (PNAISC) reforça no inciso VI do artigo 6o a atenção à saúde de crianças com deficiência ou em situações específicas e de vulnerabilidade com foco na inclusão dessas crianças nas redes temáticas de atenção à saúde através de reconhecimento das especificidades deste público para uma atenção resolutiva. Em suma, a excelência da PNAISC fundamenta-se nos eixos do Sistema Único de Saúde (SUS) que priorizam a universalidade, a integralidade e a equidade. (BRASIL, 2015).

Em 2015 foi promulgada a Lei $n^{\circ}$ 13.146, Lei Brasileira de Inclusão da Pessoa com Deficiência (Estatuto da Pessoa com Deficiência), destinada a assegurar e a promover, em condições de igualdade e sem discriminação, o exercício dos direitos e das liberdades fundamentais das pessoas com deficiência, visando à sua inclusão social e cidadania. (BRASIL, 2015). Vale ressaltar que a inclusão escolar de alunos com necessidades especiais está prevista pelo Decreto 7.611 de 2011. De acordo

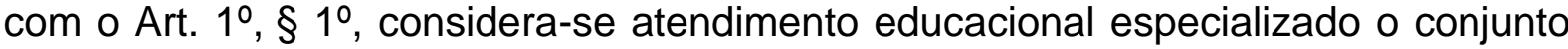
de atividades, recursos de acessibilidade e pedagógicos organizados institucionalmente, prestado de forma complementar ou suplementar à formação dos alunos no ensino regular. (BRASIL, 2011).

Ao analisar o atual contexto das escolas brasileiras, nota-se que tal prerrogativa não é válida, principalmente quando em foco a situação educacional de indivíduos portadores de deficiências, sejam elas de qualquer natureza.

O descaso com a educação inclusiva, conforme Marcus Mazzotta (1982), é calcado no estereótipo histórico que coloca o deficiente na condição imutável de "inválido", levando à marginalização desses e, consequentemente, à omissão de serviços específicos para suprir as necessidades dessa parcela populacional. (MAZZOTTA, 1982). 
O desprezo em relação a abrangência didática é comprovado nas escolas brasileiras que, em sua maioria, não possuem o aporte necessário para recepcionar os alunos com deficiência, uma vez que suas infraestruturas são inadequadas, seus docentes são despreparados e os materiais de ensino não são adaptados segundo as necessidades individuais. Sendo assim, os alunos que estão matriculados no ensino regular e necessitam de atendimento especial, majoritariamente, estão sem o receber, causando a denominada "inclusão-excludente" para se referir à lógica perversa mascarada nas políticas de generalização da Educação Básica. (FREITAS, 2002).

A fim de sanar a indiferença educacional, em 1999, foi promulgado o Decreto $n^{\circ} 3$. 298, o qual dispõe sobre a Política Nacional para a Integração da Pessoa Portadora de Deficiência, estabelecendo a matrícula compulsória das Pessoas com Deficiências, bem como considerou, no Art. 24, a Educação Especial uma modalidade educativa. (BRASIL, 1999). Além disso, foi instituído em 2007 o Programa de Saúde na Escola (PSE) que permite a interação de serviços de saúde com os serviços educacionais, objetivando, execução e monitoramento de ações de prevenção, promoção e avaliação das condições de saúde dos educandos, bem como a capacitação dos profissionais de educação. (BRASIL, 2007).

O ensino irrestrito aspira à igualdade de oportunidades, sem discriminação. (BRASIL, 2011). Essa garantia de um sistema educacional inclusivo ocorre a partir da variedade de serviços educacionais e da consideração das diversidades e das pessoalidades de cada sujeito, objetivando atender às diferenças individuais dos alunos para uma aprendizagem qualitativa e significativa, proporcionando a valorização pessoal e social. (MAZZOTTA, 1982; FERREIRA, 2005). Portanto, a presença de necessidades educacionais especiais, e não apenas a presença de uma deficiência, determina se um aluno deve receber uma educação especial. (MAZZOTTA, 1982).

\section{OBJETIVOS}

Analisar as necessidades de aprendizagem dos professores e estagiários no trabalho com crianças que possuem necessidades educacionais especiais em uma escola no interior paulista. 


\section{METODOLOGIA}

Fizeram parte da pesquisa 17 professores da Escola Prof ${ }^{a}$ Maria Martins e Lourenço e foram convidados também 45 estagiários do curso de Pedagogia do Centro Universitário de Votuporanga. A pesquisa foi realizada na Escola Prof ${ }^{a}$ Maria Martins e Lourenço que está localizada no Bairro Pozzobon e no Centro Universitário de Votuporanga, ambos localizados no mesmo município.

No primeiro momento foi realizada uma revisão bibliográfica e, em seguida, os discentes do curso de medicina aplicaram questionário, tratando-se, portanto, de uma pesquisa exploratória e descritiva, utilizando variáveis qualitativas e quantitativas.

No primeiro dia, o objetivo foi levantar dados estatísticos dos alunos do $2^{\circ}$ e $8^{\circ}$ período do curso de Pedagogia do Centro Universitário de Votuporanga - UNIFEV - para analisar a experiência destes e dificuldades encontradas na educação especial. Para tanto, inicialmente, foi justificado o motivo e objetivo do presente trabalho, além do incentivo a participação dos alunos de pedagogia.

Realizou-se, então, aplicação de um questionário para 100\% dos alunos presentes do $2^{\circ}$ e $8^{\circ}$ período do curso de Pedagogia do Centro Universitário de Votuporanga UNIFEV. Durante a realização da enquete, estavam presentes 21 alunos do $2^{\circ}$ período, entre eles 20 do sexo feminino e 1 do sexo masculino. Do mesmo modo, encontravam-se 24 alunos do 8 o período, sendo 19 do sexo feminino e 5 do sexo masculino.

O segundo dia almejou identificar as necessidades e carência de recursos dos professores e avaliar seu nível de conhecimento dos em relação a promoção da educação especial adequada, de acordo com a particularidades de cada aluno com deficiência. Dessa forma, em um primeiro momento, explicou-se os motivos, objetivos e relevância desta pesquisa, para em seguida aplicar um questionário, individual e sigilosamente, com 11 perguntas fundamentadas na realidade dos recursos, atividades, preparo, dificuldades e entre outros temas voltados para a educação especial. Durante a aplicação das questões estavam presentes 17 professores, sendo 
2 homens e 15 mulheres. Tratou-se, portanto, de uma pesquisa exploratória, descritiva com variáveis qualitativas e quantitativas. Após isso, as repostas foram analisadas pelo discentes da Unifev a fim de detectar as dificuldades apresentadas na escola.

O terceiro encontro objetivou esclarecer as dúvidas dos professores em relação às dificuldades encontradas por eles no dia a dia no que se diz respeito aos alunos com deficiência e suas particularidades. A roda de conversa foi realizada na instituição de ensino Unifev que está localizada no Bairro centro em Votuporanga- SP. No primeiro momento, a presidente da APAE de Votuporanga foi apresentada aos professores e em seguida explicou-se os motivos, objetivos e relevância desta pesquisa. Posteriormente, foi dado início à discussão, a qual abordou assuntos como inclusão social, a importância da APAE, preconceito com deficientes, além de dicas para que os professores consigam otimizar a aprendizagem dos alunos especiais em salas de aula. Durante a discussão estavam presentes 16 professores, sendo 1 homem e 15 mulheres.

\section{RESULTADOS E DISCUSSÃO}

\section{Primeiro dia:}

Gráfico 1 - Distribuição dos Alunos da Pedagogia segundo o sexo e período

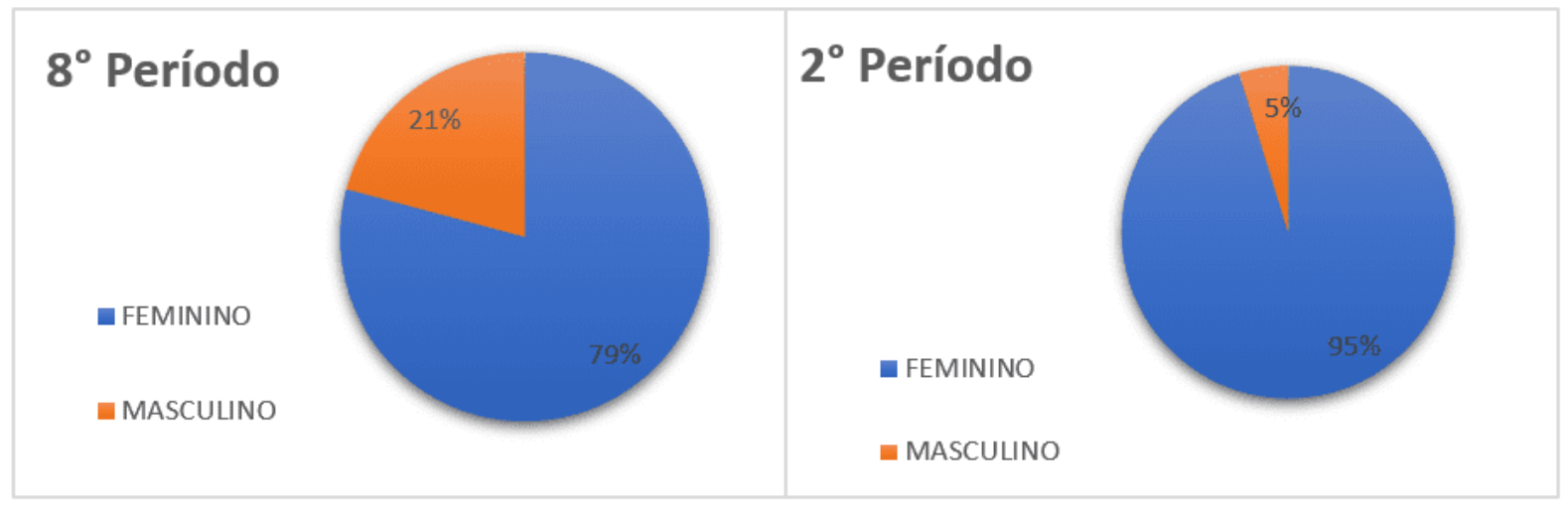

Fonte: Elaborado pelo autor (2020).

Durante a aplicação do questionário e a partir da análise do Gráfico 1, foi visível a prevalência de estudantes do sexo feminino em ambos os períodos pesquisados. Isso 
vem ao encontro do que propõe Vianna (2002), em que a feminização da educação ocorre tanto em nível profissional, quanto acadêmico e transcendem a questão da composição numérica, podendo ser identificado significados femininos nas atividades docentes independentemente de quem as realiza. Ou seja, historicamente o curso de Pedagogia foi construído a partir de práticas consideradas femininas, uma vez que a profissão envolve a educação de crianças, boas relações com os familiares, comunicação amigável, paciência, amabilidade, compreensão, condutas socialmente éticas, entre outas características, as quais são atribuídas ao sexo feminino.

Gráfico 2 - Distribuição dos Alunos do $2^{\circ}$ Período da Pedagogia de acordo com sexo e idade

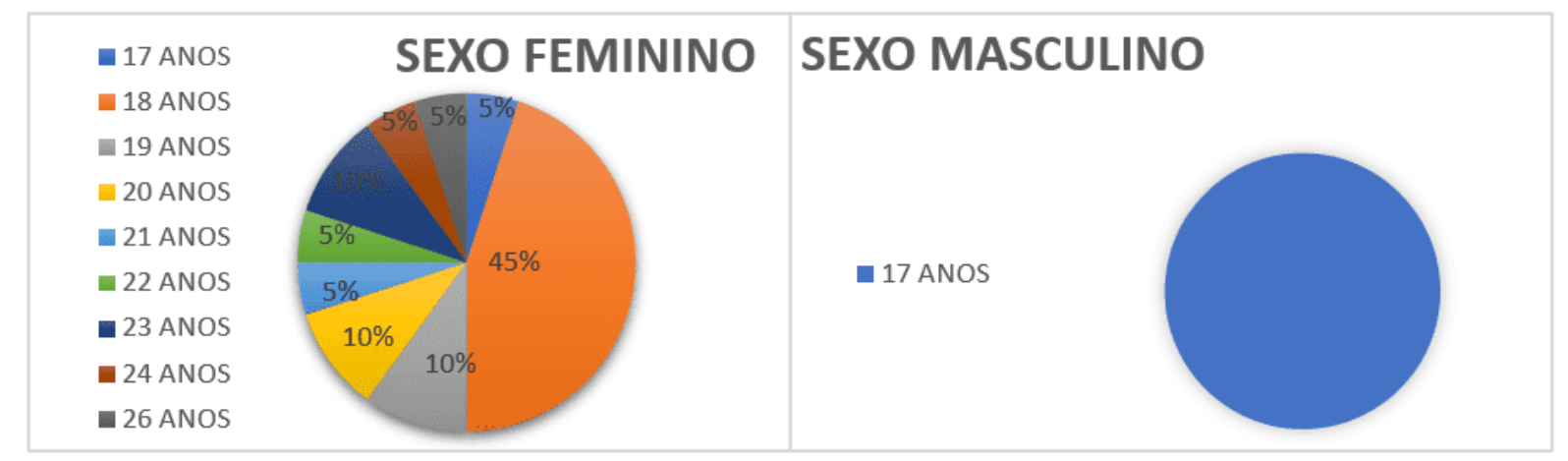

Fonte: Elaborado pelo autor (2020).

Gráfico 3 - Distribuição dos Alunos do $8^{\circ}$ Período da Pedagogia de acordo com sexo e idade

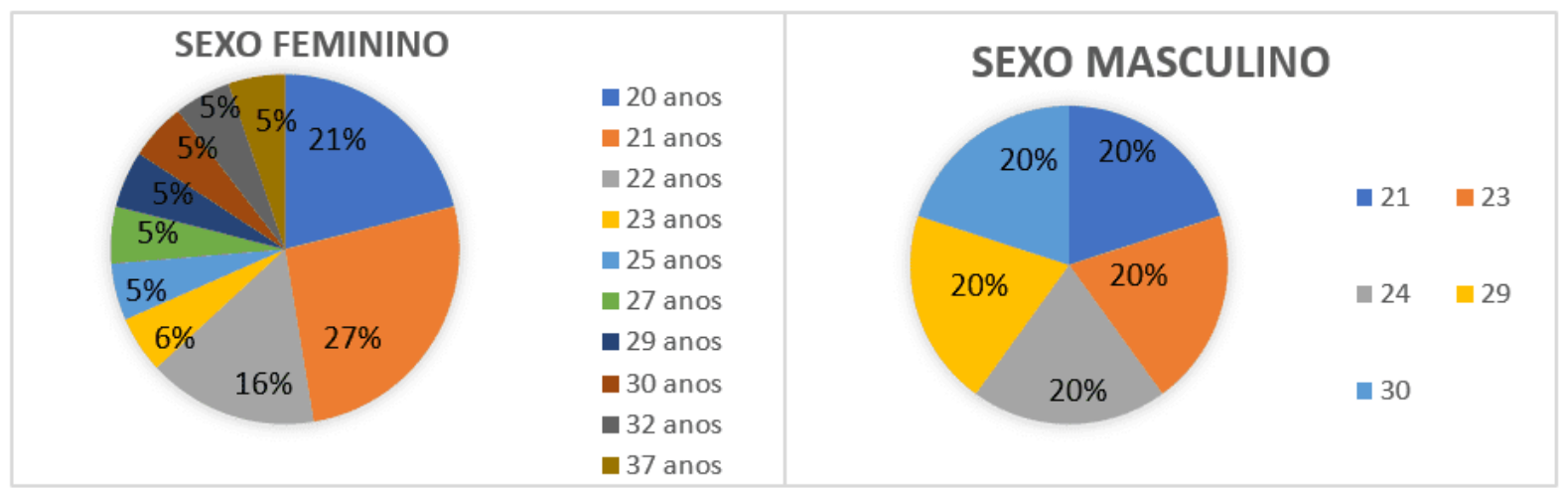

Fonte: Elaborado pelo autor (2020). 
Analisando os parâmetros de idade encontrados nas salas (gráficos 2 e 3), foi possível observar a predominância de acadêmicos jovens. No 2 o período, os estudantes são, majoritariamente, da faixa etária entre 17 e 18 anos, enquanto no $8^{\circ}$ período a maioria está entre 20 e 23 anos. Essa precocidade ou anseio pelo ingresso no ensino superior concorda com o proposto por Bloss (1998), o qual considera a profissionalização como parte fundamental para consolidação dos interesses do ego na fase final da adolescência. Dessa forma, a maioria dos jovens procura ingressar o quanto antes tendo em vista o anseio de um futuro promissor através do ensino superior. (BLOSS, 1998).

Gráfico 4 - Distribuição dos Alunos da Pedagogia do $2^{\circ}$ e $8^{\circ}$ Período de acordo com a Presença de Alunos Especiais nas Escolas de Atuação dos Professores

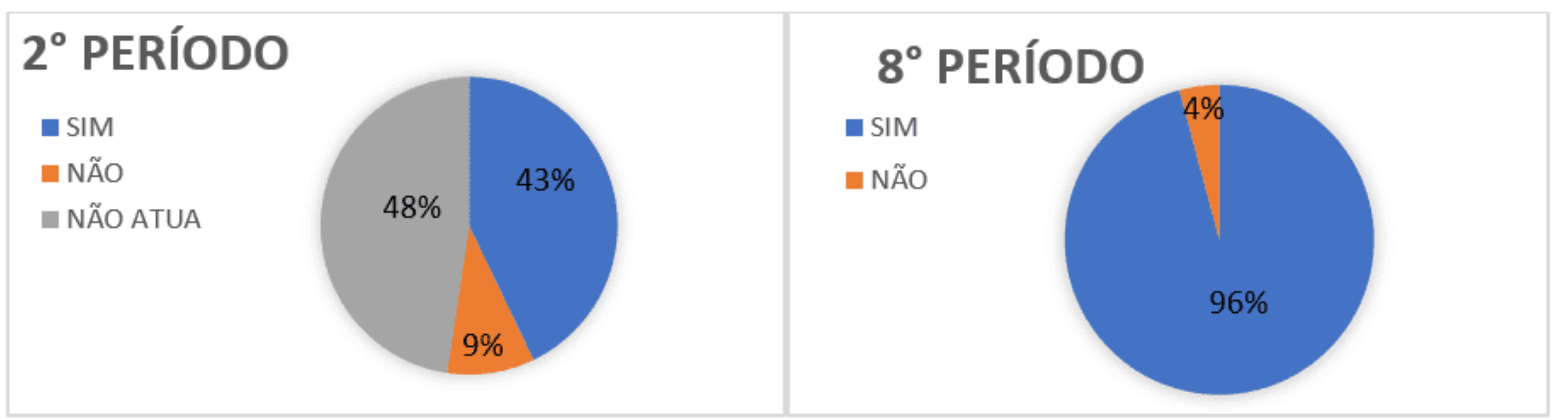

Fonte: Elaborado pelo autor (2020).

A presença de alunos com necessidades especiais nas escolas de atuação dos estagiários (Gráfico 4) é alta, sendo praticamente insignificante a quantidade de escolas que não possuem alunos especiais quando comparado com o número de estagiários atuantes. Esse panorama cumpre o proposto pela Lei de Diretrizes e Bases da Educação Nacional, Lei № 9.394/96, bem como é assegurado pela Constituição da República Federativa do Brasil (1988), as quais preconizam a adequação dos sistemas de ensino para atender as especificidades dos alunos e a educação universal. (BRASIL, 1996, 1988).

Gráfico 5 - Distribuição dos Alunos da Pedagogia do $2^{\circ}$ e $8^{\circ}$ Período de acordo com as necessidades especiais encontradas nas escolas de estágio 


\section{$2^{\circ}$ PERÍODO}

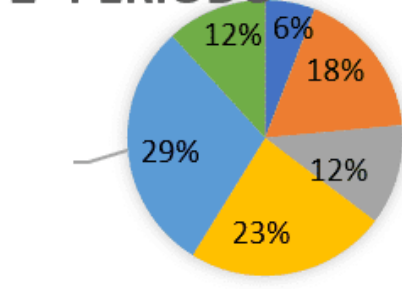

- VISUAL

FÍSICA

AUDITIVA

- PSIQUIÁTRICA

- HIPERATIVIDADE

- SINDRÔMICA

- AUTISMO

\section{$8^{\circ}$ PERÍODO}

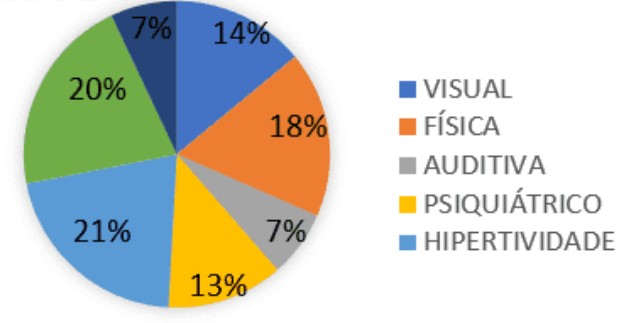

Fonte: Elaborado pelo autor (2020).

O gráfico acima permite concluir que a necessidade especial de maior incidência relatada pelos participantes da pesquisa é a hiperatividade, geralmente associada ao transtorno déficit de atenção (TDAH), o qual é considerado comum na idade escolar e obtém uma prevalência de 3 a 5\% das crianças nesta fase. (PASTURA et al., 2007). Além disso, é válido ressaltar que existe uma alta incidência de procura de atendimento já com diagnóstico não correto de TDAH, evidenciando que muitas crianças não são, de fato, portadoras de hiperatividade e que a taxa de prevalência é passível de variação. (GRAEFF et al., 2008).

Gráfico 6 - Distribuição dos Alunos da Pedagogia do $2^{\circ}$ e $8^{\circ}$ Período de acordo com as oportunidades de preparo em Educação Especial

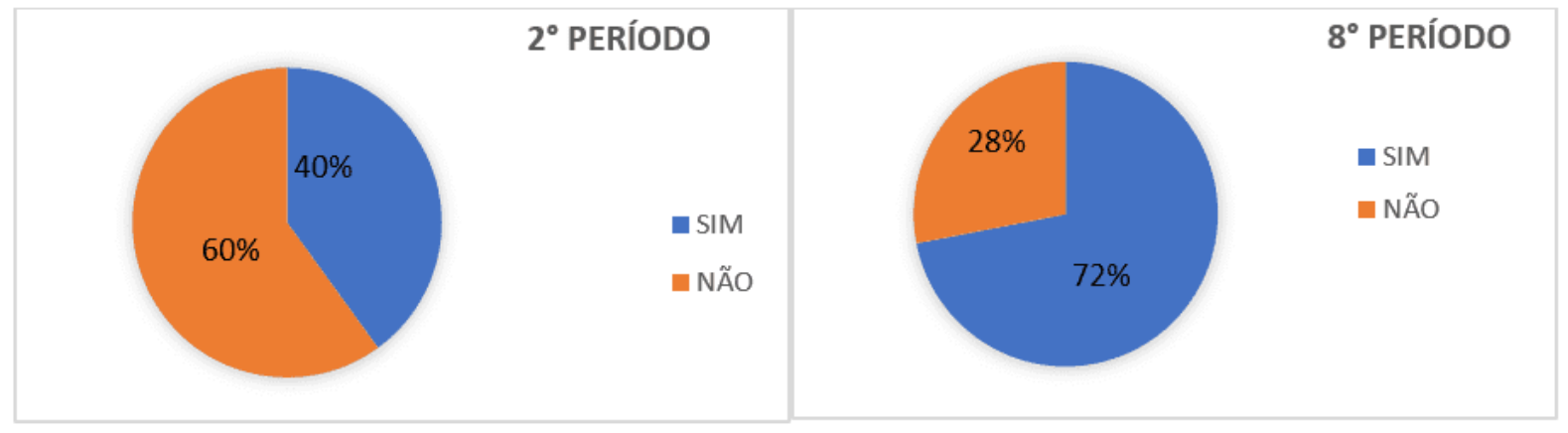

Fonte: Elaborado pelo autor (2020).

A partir dos resultados apresentados pelos gráficos 6 , pode-se observar uma discrepância de respostas entre o $2^{\circ}$ e $8^{\circ}$ período, a qual pode ser justificada pelo fato de que os discentes do primeiro ano do curso de pedagogia entrarão em contato com a grade curricular correspondente à educação especial nos próximos períodos. Diante 
disso, é válido salientar que o ensino à criança especial incorpora a inclusão social, ou seja, é uma porção da aceitação, por parte dos professores, de que esse ensino é de sua responsabilidade e, por isso devem ser preparados para tal trabalho. (MITTLER, 2003).

Gráfico 7 - Distribuição dos Alunos da Pedagogia do $2^{\circ}$ e $8^{\circ}$ Período de acordo com as dificuldades encontradas em realizar atividades educacionais com alunos especiais

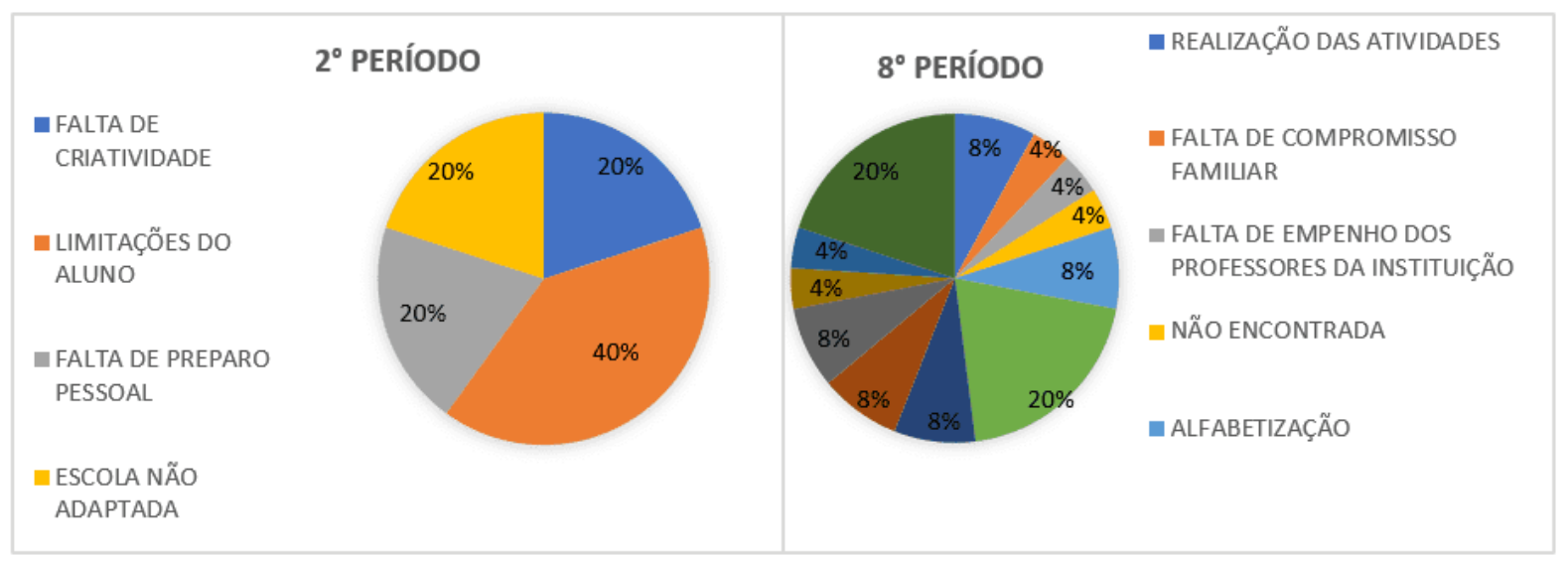

Fonte: Elaborado pelo autor (2020).

Gráfico 8 - Distribuição dos Alunos da Pedagogia do $2^{\circ}$ e $8^{\circ}$ Período de acordo com o acesso de preparação para educação especial

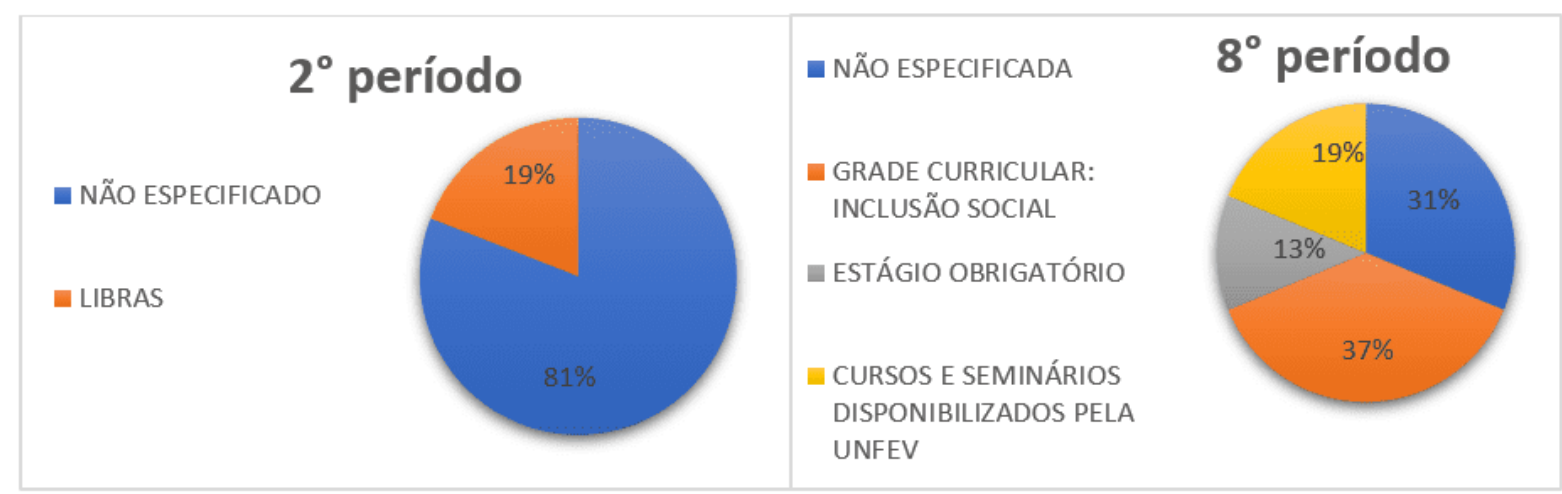

Fonte: Elaborado pelo autor (2020).

Os gráficos 7 e 8 apontaram que a falta de preparo dos professores quanto à educação especial é a principal dificuldade no trabalho com os alunos especiais, o que reflete diretamente nas limitações do aluno (principal causa apontada pelos 
discentes do $2^{\circ}$ período), isto é, a ausência da preparação faz com que as dificuldades do aluno especial se tornem um empecilho para a aprendizagem do mesmo. Sendo assim, é necessário que tanto os discentes do curso de pedagogia quanto os profissionais já atuantes sejam capacitados para a educação especial, tomando por base o fato de a presença do professor ser de suma importância para o ensino de todo e qualquer ser humano, uma vez que é ele quem está em contato direto com o aluno. (SKINNER, 1972). Além disso, é possível afirmar que uma parte dos discentes do primeiro ano já buscam alguma forma de preparação para lidar com alunos especiais antes de entrarem em contato com a grade curricular correspondente a tal assunto, enquanto que a maioria dos discentes do último ano do curso confiam o seu embasamento para a educação especial apenas à grade curricular do curso.

Gráfico 9 - Distribuição dos Alunos da Pedagogia do $2^{\circ}$ e $8^{\circ}$ Período de acordo com a adaptação das escolas de atuação para as necessidades especiais

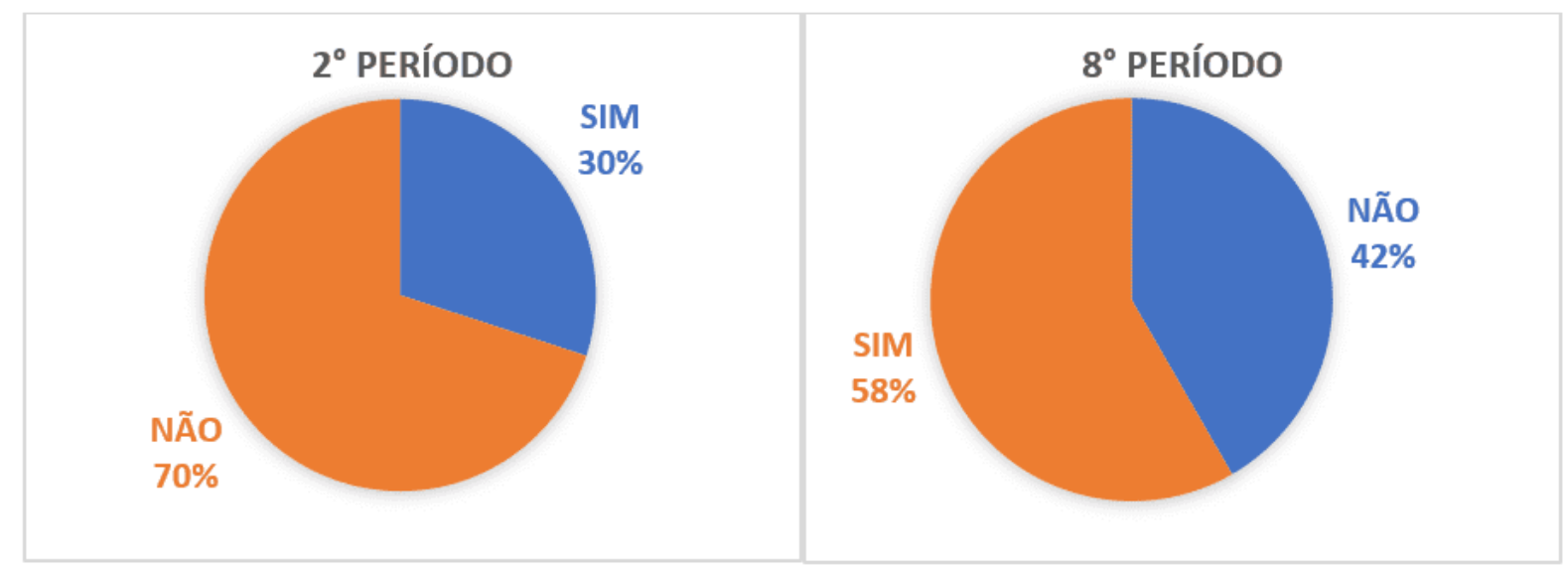

Fonte: Elaborado pelo autor (2020).

Gráfico 10 - Distribuição dos Alunos da Pedagogia do $2^{\circ}$ e $8^{\circ}$ Período de acordo com as necessidades de incrementação de infraestrutura nas escolas de atuação 

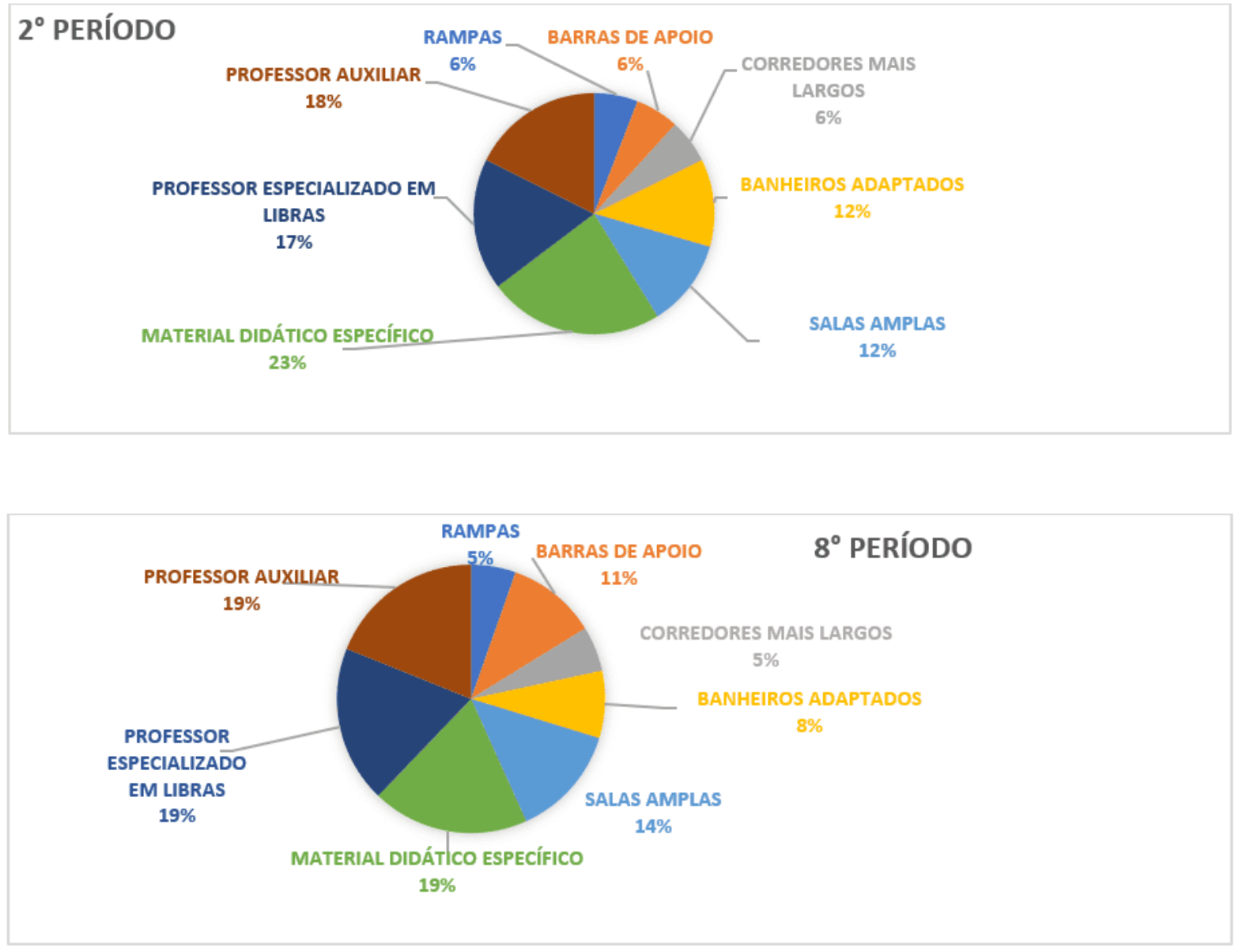

Fonte: Elaborado pelo autor (2020).

Nivelando os índices de adaptação das escolas em que os estagiários atuam, fica evidente a grande maioria das escolas isentas de estrutura física e psicológica adequada para receber alunos especiais, sendo $70 \%$ das escolas dos estagiários do 20 período e $58 \%$ das escolas dos estagiários do 8ำ período. Em suma, para caracterizar tal carência os estagiários citaram a falta de material didático específico, ausência de professor especializado em libras e a ausência de professor auxiliar, como os principais motivos de insuficiência para uma pertinente abrangência da educação especial nas escolas. Além disso, possuem como adversidades encontradas também, ausência de rampas e barras de apoio, corredores e salas estreitas e banheiros sem adaptação. Desse modo, é notório uma grande incongruência na realidade vivenciada pelos estagiários e as leis brasileiras que regem o ensino especial, especialmente devido a existência da Política Nacional de Educação Especial que na Perspectiva da Educação Inclusiva tem como objetivo o 
acesso, a participação e a aprendizagem dos estudantes com necessidades educacionais especiais, garantindo a acessibilidade urbanística, arquitetônica, nos mobiliários e equipamentos, nos transportes, na comunicação e na informação oferecidos para tais alunos. (BRASIL, 2008)

Gráfico 11 - Distribuição dos Alunos da Pedagogia do $2^{\circ}$ e $8^{\circ}$ Período de acordo com a percepção da Resistencia encontrada por profissionais da educação em atuar junto a alunos com necessidades especiais
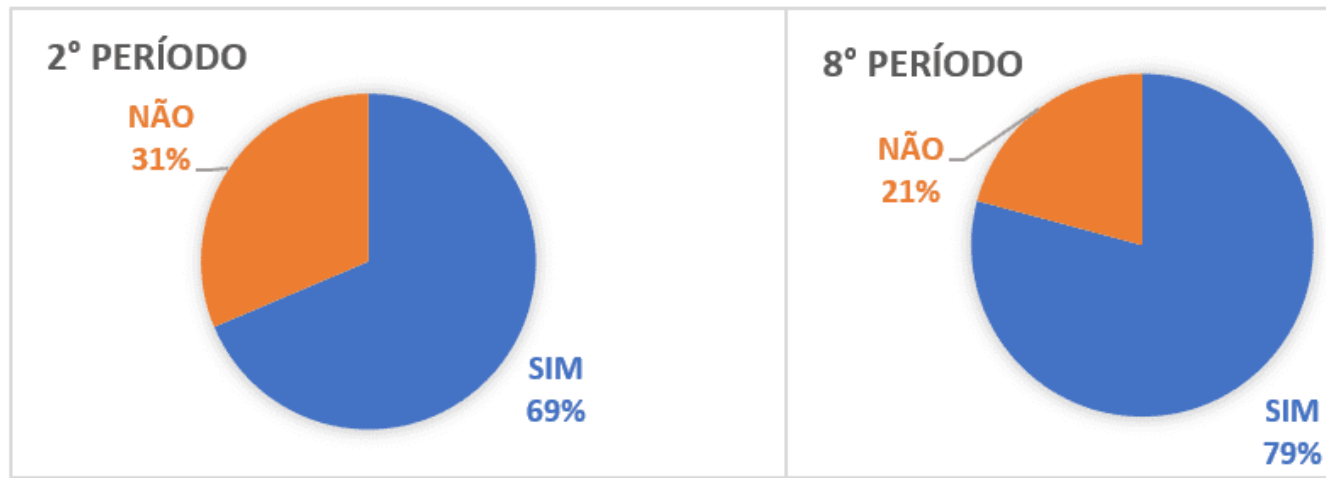

Fonte: Elaborado pelo autor (2020).

Gráfico 12 - Distribuição dos Alunos da Pedagogia do $2^{\circ}$ e $8^{\circ}$ Período de acordo com os tipos de resistências encontradas

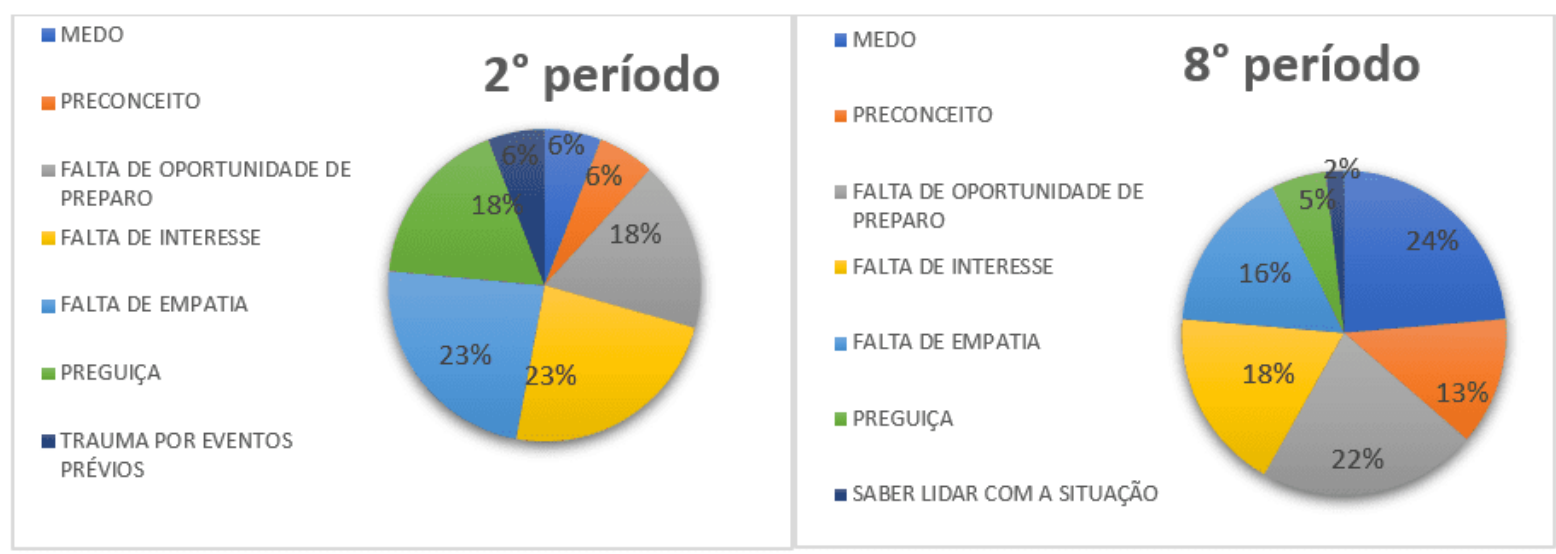

Fonte: Elaborado pelo autor (2020).

No gráfico 12, percebe-se uma equivalente percepção entre os alunos do $2^{\circ}$ e $8^{\circ}$ períodos em relação a resistência dos profissionais da educação para lidar com a 
educação especial. Infelizmente, acredita-se que esta reação esteja alicerçada em fatores que dizem respeito a conceitos históricos relacionados às pessoas com deficiência, ao alunado da educação especial e, também, aos discentes dos últimos períodos de pedagogia, que acreditam que não se depararão com tais estudantes. (HONNEF, 2011).

Pormenorizando os motivos para esta resistência, os discentes de pedagogia colocam como falta de preparo, de interesse e de empatia as principais causas para a relutância dos educadores com o ensino especial. Além desses pretextos, foram citados também, medo, preguiça e preconceito, o que deixa claro a urgente necessidade de desconstruir mentalidades, posturas e comportamentos, além de demonstrar que as políticas de caráter universalista não têm conseguido efetivar o que prometem: tratar a todos igualmente. (CURY, 2005).

Gráfico 13 - Distribuição dos Alunos da Pedagogia do $2^{\circ}$ e $8^{\circ}$ Período de acordo com a presença de profissionais específicos para atuar com alunos especiais nas escolas de estágio

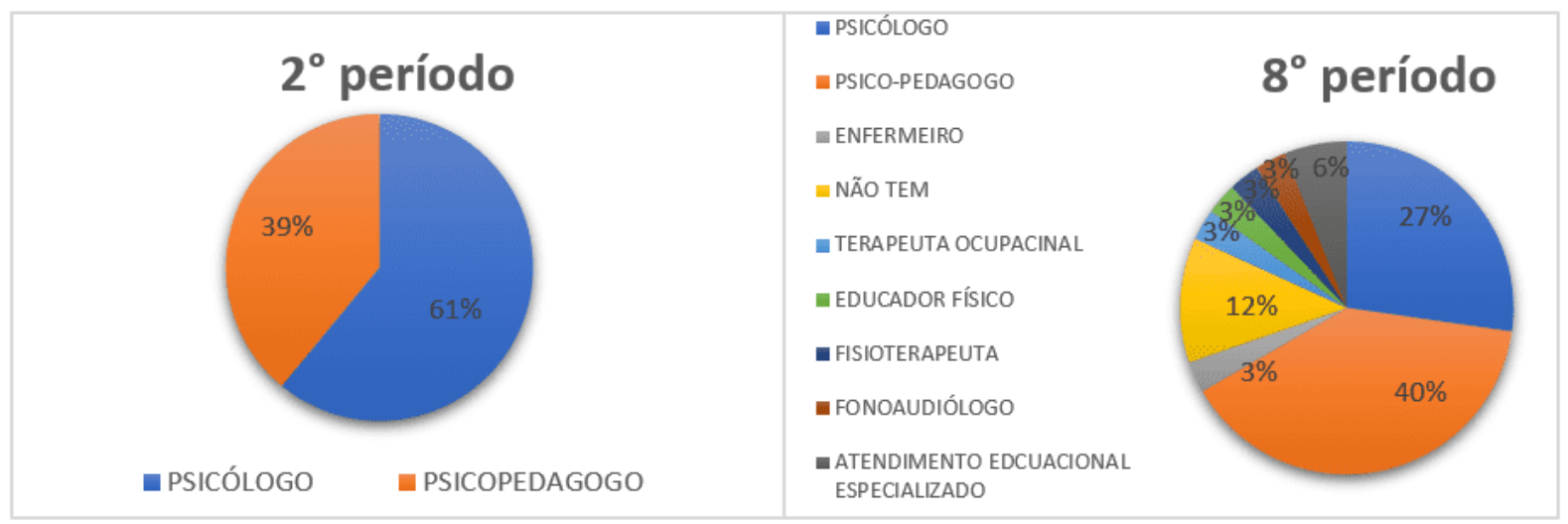

Fonte: Elaborado pelo autor (2020).

A formação dos professores também se encontra entre as demandas mais emergentes para a efetividade do processo de inclusão, pois, atualmente, é consenso que a qualificação dos educadores influencia no avanço da reforma educacional. Dessa forma, o despreparo dos professores configura um dos obstáculos mais citados para a educação inclusiva, o qual tem como efeito o estranhamento do educador com 
aquele sujeito que não está em conformidade com "os padrões de ensino e aprendizagem". (BRASIL, 2005). Esse quadro vem ao encontro dos Gráficos 25 e 26, pois há uma baixa atuação de professores formados em educação especial (6\%) ou em cursos voltados para o bem-estar dos alunos com disfunção funcional (fonoaudiólogo - 3\%; fisioterapeuta - 3\%; terapeuta ocupacional 3\%). Ao mesmo tempo, nota-se escolas com ausência de quaisquer profissionais (12\%). Entretanto, há uma preocupação com a saúde mental dos alunos, a qual pode interferir no processo de aprendizagem.

Gráfico 14 - Distribuição dos Alunos da Pedagogia do $2^{\circ}$ e $8^{\circ}$ Período de acordo com as atividades realizada específicas para alunos especiais

\section{$2^{\circ}$ período \\ - ACOMPANHAMENTO PEDAGÓGICO \\ a REFORÇO ESCOLAR \\ E ESPORTES \\ aRTE \\ -APOIO DE ESTAGIÁRIOS}

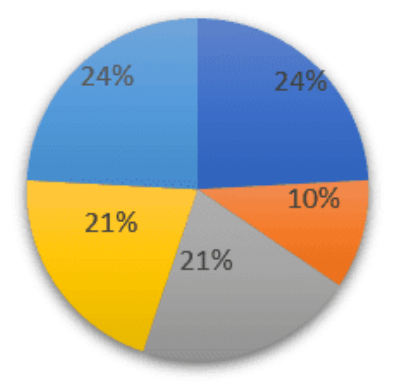

\section{$8^{\circ}$ período}

- ACOMPANHAMENTO PEDAGÓGICO

- REFORÇO ESCOLAR

- ESPORTES

ARTES

APOIO DE ESTAGIÁRIOS

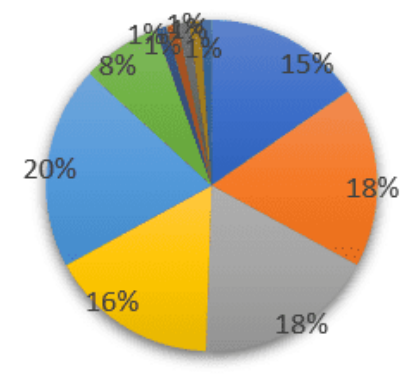

Fonte: Elaborado pelo autor (2020).

No que se refere às atividades realizadas nas escolas em que os estagiários atuam (Gráfico 14), observa-se que o $2^{\circ}$ período, por ter menos experiência sobre a área de atuação, dispõem de um leque de atividades menor daqueles do $8^{\circ}$ período e que esse ano possui uma limitação de recursos complementares ofertados pelas instituições de ensino. Esse cenário é passível de preocupação, pois a atuação do educador deve ir além da transmissão do conteúdo curricular, priorizando a assimilação pelo aluno, já que sem ela não haverá aprendizagem, memorização e aplicação prática dos conhecimentos. Dessa forma, é necessário haver um ambiente escolar que permita a acessibilidade ao ambiente físico e instrumental (materiais e recursos que minimizem as dificuldades sensoriais e motoras); tenha práticas motivadoras, alegres e afirmativas; haja estratégias ricas em estimulação e 
diversificadas quando necessário (por exemplo, recursos audiovisuais, objetos de diferentes materiais, cores e texturas); sejam realizadas atividades mais tranquilas e que trabalhem a memória associativa; que haja uso de tecnologias assistivas (TAs) e tecnologias de informação (Tls) para integrar as estratégias de estimulação dos processos cognitivos; entre tantos outros recursos que possam proporcionar uma real formação do aluno especial não apenas academicamente, mas também voltada para o convívio social. (SANTOS, 2012).

Gráfico 15 - Distribuição dos Alunos da Pedagogia do $2^{\circ}$ e $8^{\circ}$ Período de acordo com os recursos utilizados para a inclusão nas escolas de estágio

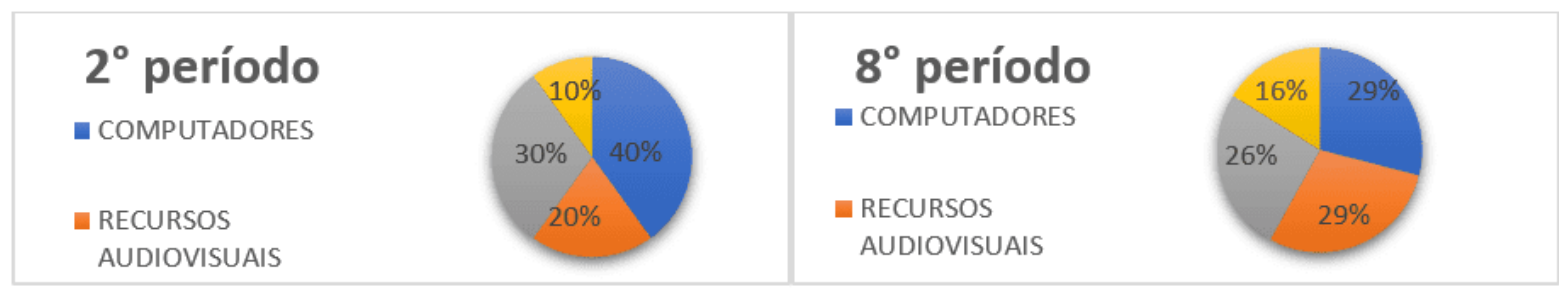

Fonte: Elaborado pelo autor (2020).

A partir da análise dos gráficos 29 e 30, fica evidente que prevalece o uso de computadores como forma de promover a inclusão na escola, sendo que $40 \%$ das escolas dos estagiários do $2^{\circ}$ período e $29 \%$ das escolas dos estagiários do $8^{\circ}$ período. Este fato possui relevância dentro do contexto de formação educacional especial, uma vez que as tecnologias assistidas organizam e fortalecem a linguagem, permitindo a comunicação efetiva e a aquisição de habilidades escolares e sociais, vitais para assegurar seu pleno desenvolvimento e autonomia, para realização de atividades tanto na escola quanto fora dela. (HEIDRICH, 2003).

Gráfico 16 - Distribuição dos Alunos da Pedagogia do $2^{\circ}$ e $8^{\circ}$ Período de acordo com maiores dificuldades encontradas para trabalhar com aluno especial 


\section{$2^{\circ}$ PERÍODO}

- INCLUSÃO E LIMITAÇÕES DO ALUNO

- DIFICULDADE EM ENTENDER AS CARACTERÍSTICAS ESPECÍFICAS DO ALUNO

= NÃO INTERESSE PEAGÓGICO DOS GESTORES

- PSICOSOCIAL FAMIUAR

- PACIÊNCIA

- DIFICULDADE EM LIDAR COM AGRESSÕES FÍSICAS

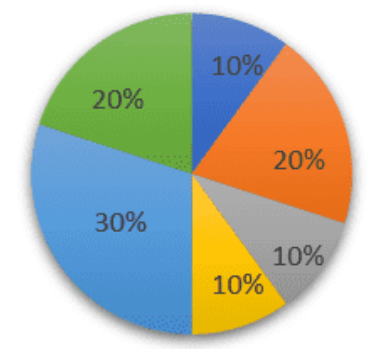

\section{$8^{\circ}$ PERÍODO}

- Falta de ESPAÇO

- FALTA DE ORIENTAÇÃO PARA OS PRFISSIONAIS

— FALTA DE INTERESSE DOS FAMILIARES

ALFABETIZAÇÃO

- PRECONCEITO

- FALTA DE RECURSOS

Fonte: Elaborado pelo autor (2020).

Analisando o gráfico 16, é possível perceber a presença visível da preocupação com a ausência do interesse da família em se envolver com a educação encontradas pelo $2^{\circ}$ e $8^{\circ}$ período de Pedagogia. A participação da família corresponde aos ideais pedagógicos da gestão democrática participativa e na compreensão que, o trabalho conjunto, pode trazer muitos benefícios à escola e aos alunos, garantindo o aumento das condições para um melhor aprendizado e desenvolvimento da criança. (BRASIL, 1996). Porém, mesmo sendo de extrema importância a interação entre família e escola, percebe-se que ainda é relativamente baixa a participação dos pais na escola.

Levando em conta a inexperiência do $2^{\circ}$ período na área prática, devido ao seu ingresso recente no âmbito pedagógico, é perceptível o receio quanto à paciência ao lidar com alunos especiais. Tal receio demonstra empatia e é de suma importância pois professores de educação especial salientam que deve haver uma motivação genuína, diálogo, paciência, comprometimento e responsabilidade do professor em planejar pensando no aluno para que a inclusão aconteça. (THESING et al., 2018).

Por outro lado, a maior ansiedade dos estagiários do $8^{\circ}$ período, por estarem próximos ao egresso, é a falta de orientação para os profissionais. Segundo Bueno (1999), diante das condições atuais da educação no Brasil, não é possível incluir crianças 
com necessidades educativas especiais em um ensino regular sem o apoio de um profissional especializado com alguma orientação e auxílio. Deste modo, uma educação inclusiva é aquela composta por um ensino adaptado de acordo com as diferenças e as necessidades de cada aluno, de modo integrado ao sistema regular. Assim, o quesito imprescindível para que este conceito seja efetivado é a formação adequada e contínua do professor. (SANT'ANA, 2005).

\section{Segundo Dia:}

Gráfico 17 - Distribuição dos Professores segundo o sexo.

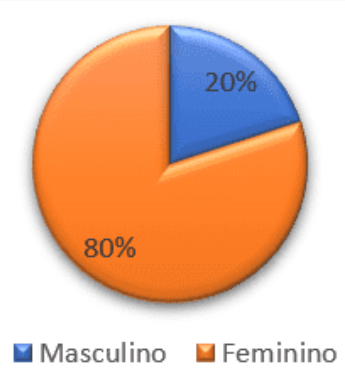

Fonte: Elaborado pelo autor (2020).

Gráfico 18 - Idade segundo o sexo.

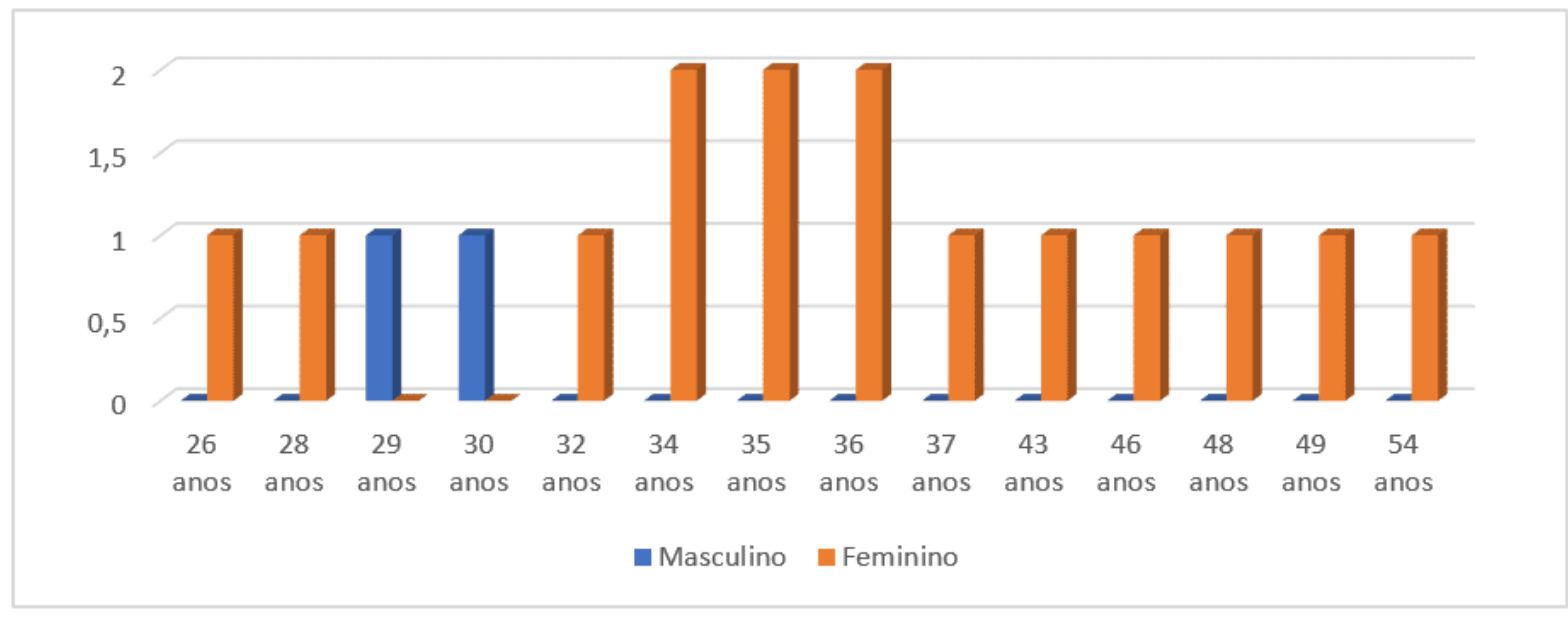

Fonte: Elaborado pelo autor (2020).

De acordo com os gráficos 17 e 18, a maior parte dos profissionais da educação são do sexo feminino (80\%) com idade de 36 anos, enquanto apenas $20 \%$ são homens, 
sendo estes entre 29 e 30 anos. Esse panorama está de acordo com o censo brasileiro de 2010, no qual mais da metade da população brasileira era composta por mulheres $(51,03 \%)$, sendo que a faixa etária dos 35 - 39 anos representava $3,7 \%$ desse total. (IBGE, 2010).

Além disso, nota-se que entre profissionais de pedagogia há um predomínio feminino, pois essa atividade profissional é marcada pelo cuidado, amor, paciência, dedicação, vigilância e zelo, características historicamente femininas. (LOURO, 1997). Sendo assim, a profissão de educador é considerada uma extensão do lar, o que, por muitas vezes, cria estereótipos e preconceitos quanto aos seus graduandos e profissionais, evidenciando um machismo ainda enraizado na sociedade brasileira.

Gráfico 19 - Presença de Alunos Especiais nas Escolas de Atuação dos Professores.

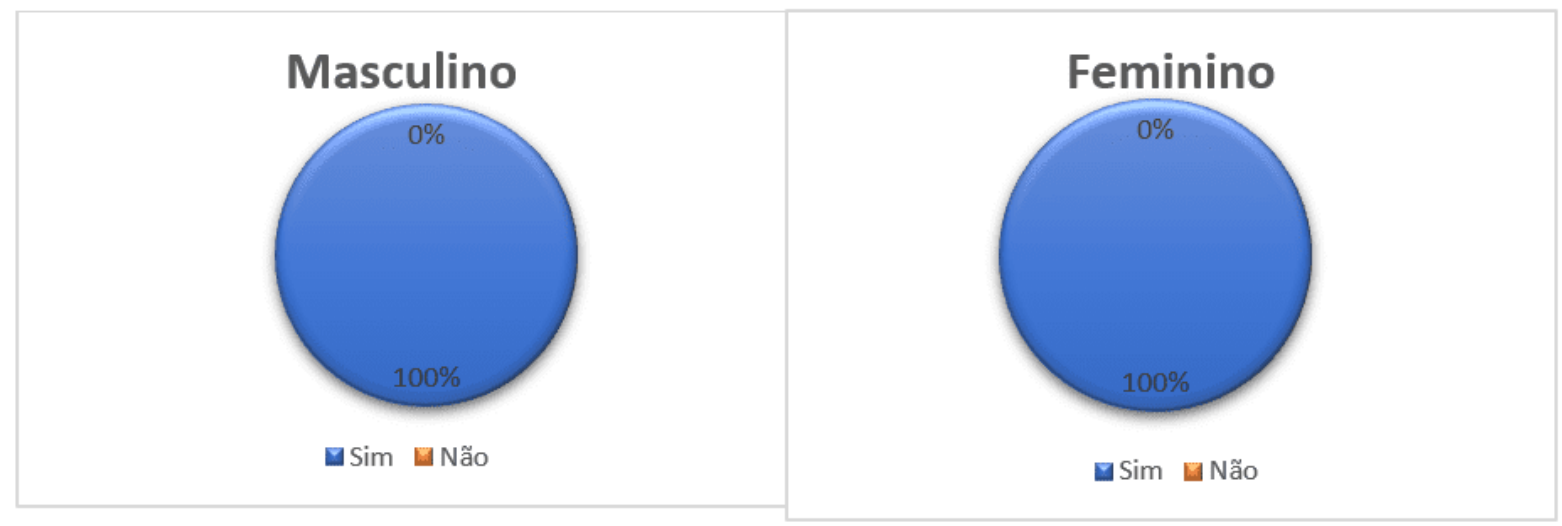

Fonte: Elaborado pelo autor (2020).

O gráfico 19 indica que todos os professores, de ambos os sexos, possuem alunos com necessidades especiais em suas salas de aula. Esse quadro está em consonância com a Constituição Brasileira de 1988 que estabelece a educação como um direito inviolável e para todo. (BRASIL, 1988). Esse fato é reafirmado através da Lei oㅜ 13.146 de 2015, na qual a educação é considerada um direito das crianças com necessidades singulares, além de determinar que o aprendizado seja ofertado com apoio escolar, práticas pedagógicas inclusivas, formação de professores em educação especial, entre outros. (BRASIL, 2015). 
Gráfico 20 - Distribuição da prevalência dos tipos de deficiência nas escolas de atuação dos professores.

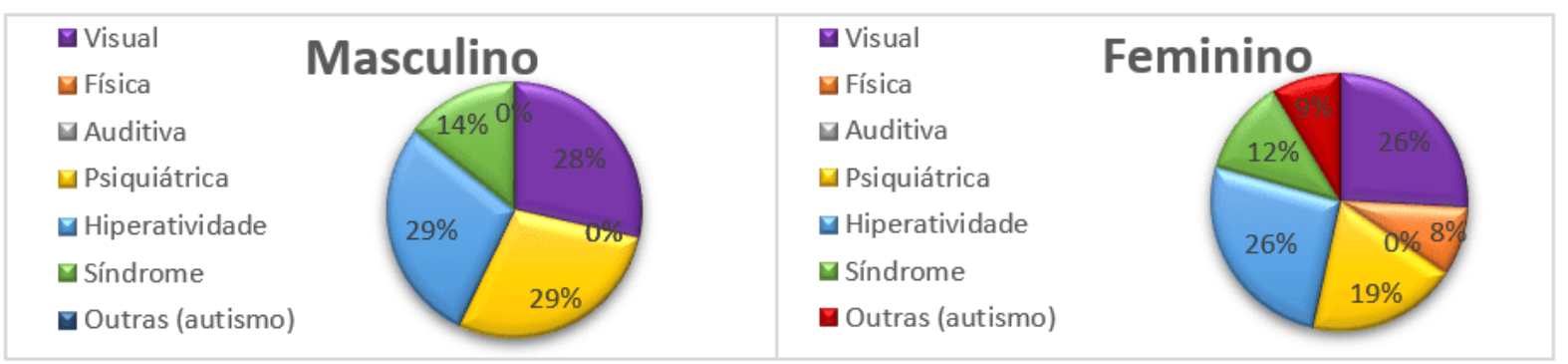

Fonte: Elaborado pelo autor (2020).

No gráfico 20, nota-se uma prevalência das necessidades psiquiátricas, visuais, hiperatividade (TDAH) e autismo, seguido das síndromes e deficiência física.

Considerando as necessidades psíquicas, os transtornos mentais e comportamentais exercem forte impacto sobre os indivíduos, as famílias e as comunidades. Os indivíduos sofrem não apenas por sua patologia, mas também por estarem excluídos de atividade sociais (por exemplo, trabalho e lazer) em virtude da discriminação. (SANCHES et al., 2011). Nesse sentido, deve-se considerar que a reinserção social do indivíduo com transtorno mental implica o envolvimento no ambiente escolar, uma vez que esse constitui o principal local de criação de vínculos social e afetivos durante a infância.

Com referência aos alunos com necessidades visuais, os profissionais da educação precisam deter conhecimentos sobre as limitações desses indivíduos, bem como sobre o sistema de ensino e reabilitação para os mesmos. A escola e a reabilitação devem atuar em conjuntos, objetivando suprir as reais dificuldades da criança deficiência visual. (MONTILHA, 20019). Tendo isso em vista, as escolas devem oferecer materiais ampliados ou em braile, aula de braile, atividades sensoriais, entre outras maneiras de incluir o aluno no ambiente escolar e social.

Em relação ao TDAH, as principais manifestações clínicas da doença são percebidas nas salas de aula através de comportamentos dispersivos, excesso de agitação, baixo desempenho, entre outras. Sendo assim, é necessário a capacitação dos profissionais 
da educação no sentido de aguçar suas percepções acerca de alterações comportamentais de seus alunos, visando possíveis encaminhamentos e diagnósticos precoces. Somado a isso, a melhor qualificação do professor possibilita otimizar o aprendizado da criança com TDAH através de atividades mais lúdicas e metodologias mais participativas. Nesse sentido, tais ações positivas, praticadas pelo professor, podem gerar significativas mudanças no processo de aprendizagem do aluno, consolidando-o. (DE LIMA, 2014).

No tocante aos alunos com Transtorno do Espectro Autista (TEA), esses se caracterizam por apresentar comprometimento ou acentuação do desenvolvimento intelectual, restrições no convívio social, na comunicação e nas atividades de interesses, sendo essas manifestações clínicas extremamente especificas de cada indivíduo. (CABRAL et al., 2017). Dessa forma, faz-se necessário que o professor tenha ciência sobre individualidades e especificidades de cada aluno com TEA para a elaboração das aulas, bem como inclusão da criança na turma. (FERRAIOLO et al., 2011).

No que diz respeito aos alunos portadores de Síndromes, por um longo tempo acreditou-se que essas pessoas eram incapazes de aprender e, por isso, eram excluídas das escolas. Atualmente, mesmo com tantas informações sobre as diversas síndromes, o preconceito persiste, sendo considerado a maior barreira para a inclusão desses alunos. (SOUSA et al., 2017).

$\mathrm{Na}$ perspectiva dos alunos com deficiência física, esses têm a sua escolarização prejudicada mesmo em situações comuns no ensino devido às limitações de locomoção, postura, uso das mãos, vigor, vitalidade e agilidade. (MAZZOTTA, 1993). Por conseguinte, precisam ser atendidos como um todo por profissionais qualificados e conscientes das necessidades educacionais que eles podem requerer no contexto da escola regular. (MELLO et al., 2013).

Finalmente, no que se refere à deficiência auditiva, é inegável que grande parte dos alunos surdos sofreu exclusão escolar ao longo da história devido às dificuldades decorrentes da linguagem. Logo, as crianças surdas, majoritariamente, encontram-se 
defasadas na escolarização, sem o adequado desenvolvimento e com um conhecimento abaixo do esperado para sua idade. Sendo assim, há a necessidade urgente de elaboração de propostas educacionais que supram às necessidades dos sujeitos surdos, favorecendo o desenvolvimento intelectual, motor, psicológico e social. (LACERDA, 2006).

Gráfico 21 - Preparo dos professores em Educação Especial.

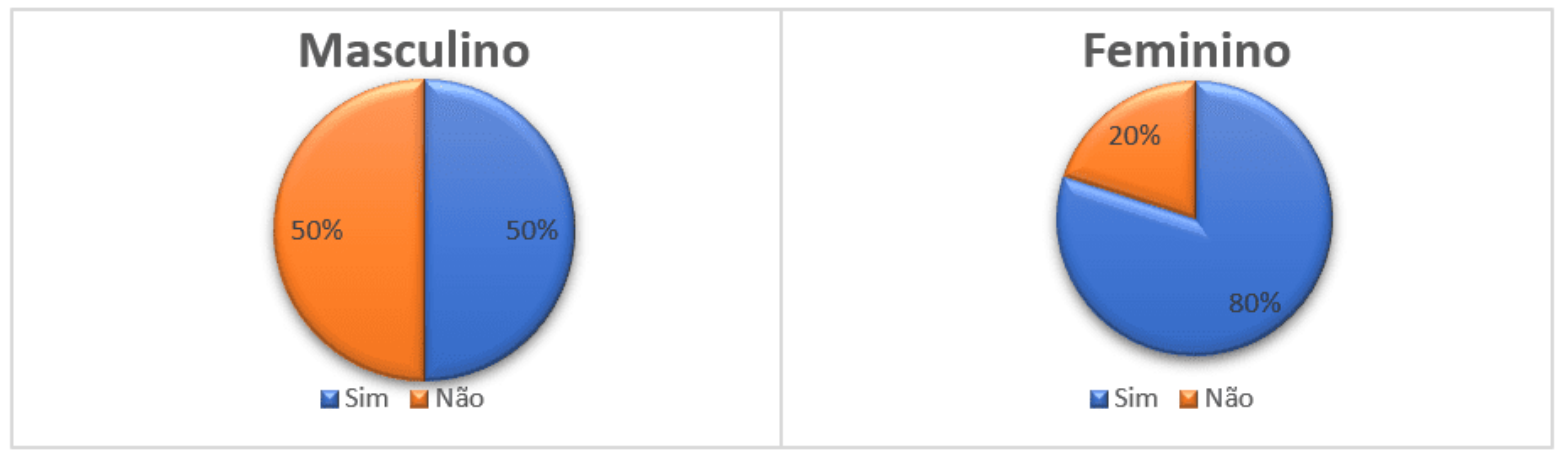

Fonte: Elaborado pelo autor (2020).

A partir do gráfico 21, nota-se que a maior parte dos profissionais tiveram oportunidades de se preparar para o trabalho com crianças com necessidades especiais ( $50 \%$ dos homens e $80 \%$ das mulheres), seja por palestras ou cursos. Dessa forma, a capacitação profissional encontra-se dentro do preconizado na Lei n ${ }^{\circ} 12.796$, de 4 abril de 2013, que em seu Art. 4º, inciso III, estabelece que os educandos om deficiência, transtornos globais do desenvolvimento e altas habilidades ou superdotação, devem receber atendimento educacional especializado e gratuito na rede regular de ensino. (BRASIL, 2013).

Entretanto, ressalta-se que ainda há professores sem qualificação, sendo que essa está diretamente relacionada à falta de conhecimentos e ao despreparo, os quais podem prejudicar a aprendizagem da criança especial. Portanto, o atual e grande desafio para os cursos de formação de professores é produzir conhecimentos para que eles possam desempenhar de maneira responsável e eficaz seu papel de ensinar e aprender para e sobre a diversidade. (PLETSCH, 2009).

Gráfico 22 - Distribuição da oportunidade em trabalhar com crianças especiais. 

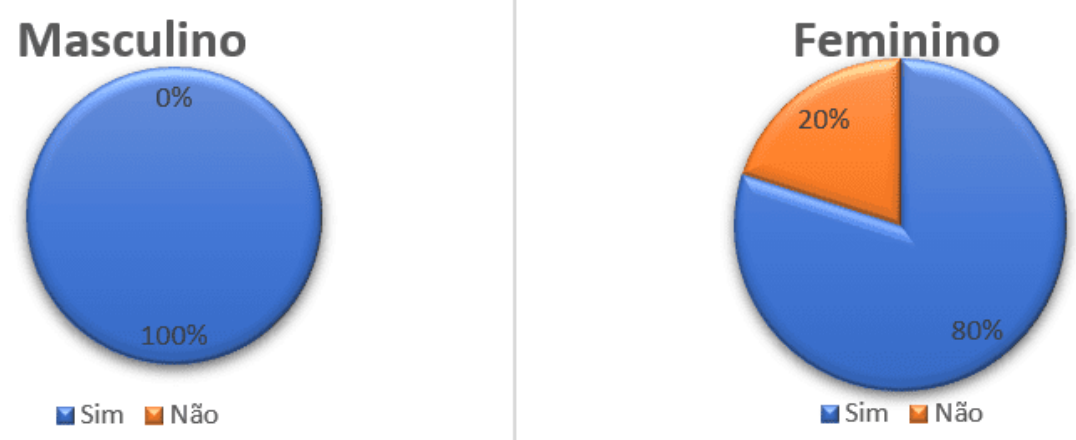

Fonte: Elaborado pelo autor (2020).

A oportunidade dos professores em lecionar para crianças com necessidades especiais também ganha destaque entre as demandas mais emergentes para o aprofundamento do processo de inclusão. Segundo a Declaração de Salamanca, todos os indivíduos com necessidades educacionais especiais devem ter acesso à escola regular e que esta seja capaz de acomodá-los dentro de uma Pedagogia centrada na criança, satisfazendo suas necessidades. (SALAMANCA, 1994). Além disso, o mesmo documento afirma que pelo princípio de educação inclusiva, em de forma lei ou de política, todas as crianças têm que serem matriculadas em escolas regulares. (SALAMANCA, 1994). Posto isso, nota-se que os dados obtidos durante a realização da pesquisa estão de acordo com o proposto pela Declaração e pelas políticas inclusivas brasileiras, visto que $100 \%$ dos professores e $80 \%$ das professoras trabalham em sala de aula com crianças especiais, o que indica uma inclusão escolar de pessoas com deficiência.

Gráfico 23 - Distribuição dos professores segundo as dificuldades encontrados no trabalho com crianças especiais. 


\section{Masculino}

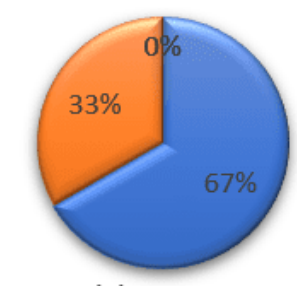

- Falta de recursos materiais

$\square$ Falta de preparo

$\square$ Inadequação das leis

$\square$ Ausência de Atendimento individualizado

\section{Feminino}

Galta de recursos materiais

$\square$ Falta de preparo

$\square$ Inadequação das leis

घAusência de Atendimento individualizado

口 Limites

Atividades adaptadas

ansiedade

Falta de acompanhamento familiar

a Sem resposta

Fonte: Elaborado pelo autor (2020).

A partir da análise do gráfico 23 , evidencia-se a falta de recursos materiais e de preparo dos professores para desenvolver as atividades com os alunos com necessidades especiais. Esses podem apresentar alterações significativas no processo de desenvolvimento, aprendizagem e adaptação social, sendo que cada aluno apresenta interesses inusitados, diferentes níveis de motivação, formas incomuns de agir, comunicar e expressar suas necessidades, desejos e sentimentos. (BRASIL, 2006). Em suma, os professores apresentam dificuldades de como lidar com as particularidades de cada aluno, pois as atividades desenvolvidas necessitarão ser reformuladas e adaptadas para alcançar maior êxito, tendo consideração nas expectativas de atitudes adequadas.

Gráfico 24 - Distribuição dos professores segundo a adaptação da escola.
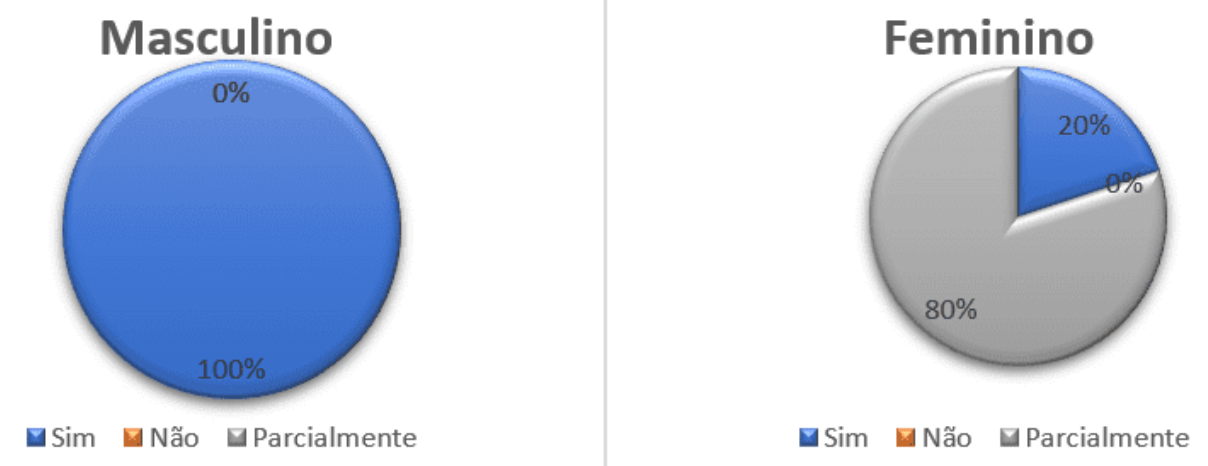

Fonte: Elaborado pelo autor (2020). 
Em relação a adaptação da escola para receber alunos especiais (gráfico 24), constata-se que os professores relataram presença de adaptação de 100\% nas escolas em que atuam, enquanto $80 \%$ das professoras relataram presença parcial de adaptação. Nesse contexto, vale lembrar que segundo a Declaração de Salamanca, os sistemas de ensino devem se adequar com as necessidades das crianças e não ao contrário, respeitando o ritmo e a natureza do processo de aprendizagem, assumindo que "as diferenças humanas são normais". (SALAMANCA, 1994). É valido salientar que a deficiência é uma característica diferente presente nessa diversidade que não pode ser negada, pois ela interfere na maneira de ser, agir e sentir das pessoas. (BRASIL,1994). Dessa forma, a Educação Inclusiva contesta a homogeneização de alunos, de acordo com os critérios que desrespeitam a diversidade humana.

Gráfico 25 - Distribuição segundo a incrementação na infraestrutura escolar.

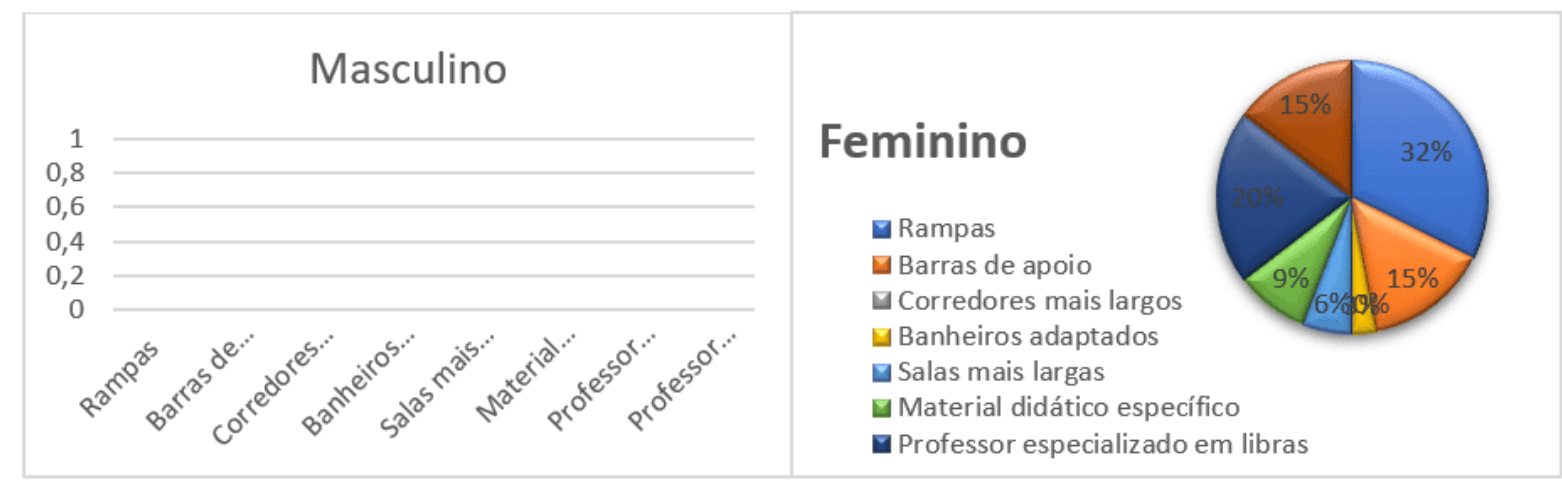

Fonte: Elaborado pelo autor (2020).

Analisando a distribuição segundo a incrementação na infraestrutura escolar (gráfico 25), foi constatado que as professoras avaliadas acreditam haver déficit de acessibilidade devido à falta de incrementação de rampas (32\%), professor especializado em libras (20\%), barras de apoio (15\%) e professor auxiliar $(15 \%)$. Portanto, a escola deverá ser capacitada para acolher os alunos com necessidades educacionais especiais que apresentam alguma deficiência física, intelectual, visual, etc. Para isso, deve-se, por meio de uma ação conjunta, promover a acessibilidade através da remoção as barreiras arquitetônicas, da adaptação mobiliária e produção 
de materiais didático-pedagógicos adaptados para esses alunos, de acordo com suas necessidades educacionais. (EDIER, 2000).

Gráfico 26 - Distribuição da Percepção de Resistencia dos profissionais em Trabalhar com Crianças Especiais.
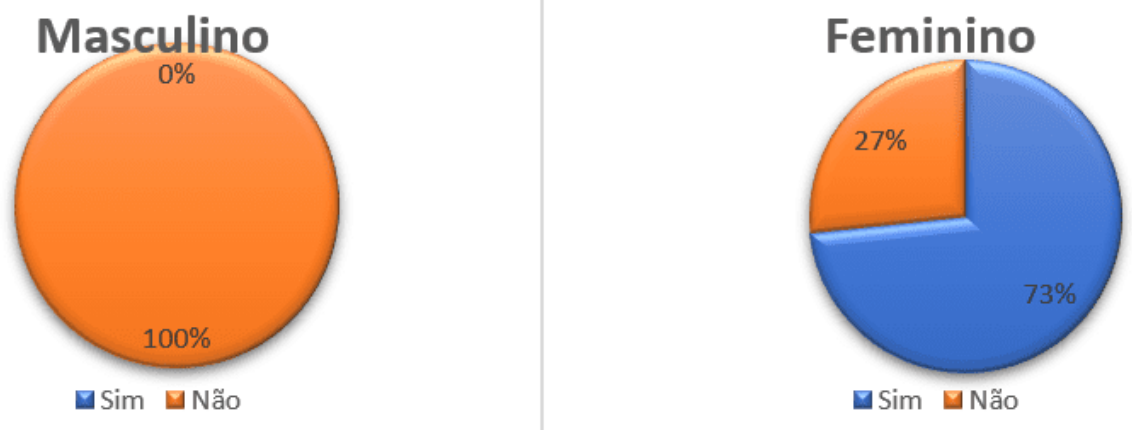

Fonte: Elaborado pelo autor (2020).

Ao analisar o gráfico 26, percebe-se que nenhum dos entrevistados do sexo masculino acredita haver resistência na profissão quando em pauta o ensino à alunos especiais. Já em relação às entrevistadas, essas demonstraram ser mais críticas, uma vez que cerca de $3 / 4$ delas afirmam encontrarem objeções. Sobre a convivência com pessoas com deficiência, salienta-se a ênfase dada a essa condição, ofuscando outras características, o que desconsidera o sujeito em sua singularidade. (NUNES et al., 2015). Consequentemente, nota-se que o preconceito de que o deficiente é sua deficiência e vive em função dela ainda persiste, eliminando o sujeito para que se sobressaia a deficiência. (AMARAL, 2004).

Na educação, o enfoque na deficiência também está presente, o que coloca em xeque a educação inclusiva, pois a crença de que a deficiência é o eixo que define e domina toda a vida pessoal e social dos sujeitos acaba por construir um vulgar processo clínico. (SKLIAR, 1997).

Gráfico 27 - Distribuição segundo o tipo de resistência encontrada 


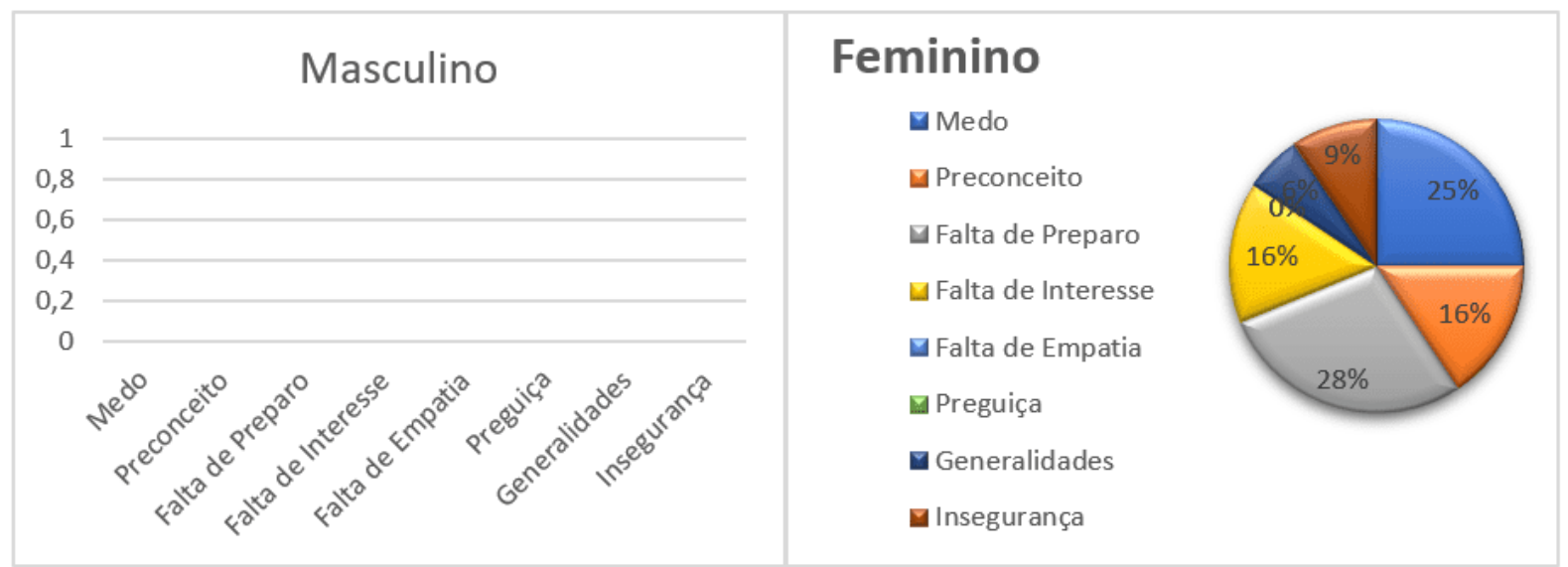

Fonte: Elaborado pelo autor (2020).

Em relação aos dados abrangidos no gráfico 27, nota-se que nenhum dos entrevistados do sexo masculino acredita haver resistências por parte de seus colegas de profissão para o trabalho com crianças especiais. Já no sexo feminino, a maior parte das mulheres $(73 \%)$ dizem perceber aversões no exercício da profissão quando essa está relacionada ao processo de aprendizagem mais dificultoso, sendo que há uma maior incidência na falta de preparo durante formação do profissional pedagogo (28\%), seguida do medo de atuação (25\%) devido à agressão física e à responsabilidades no processo de crescimento e desenvolvimento intelectual, por exemplo, e falta de interesse do profissional em adquirir conhecimentos, além da presença do preconceito (16\%). Tendo isso em vista, apesar da inclusão escolar ser garantida através do inciso III do Art. 208 da Constituição Brasileira que refere ao atendimento educacional especializado na rede regular de ensino; ser reiterada pela Política Nacional de Educação Especial que almeja apoiar o sistema regular de ensino para a inserção dos portadores de deficiências, entre tantas outras políticas governamentais, a inserção de alunos especiais ainda esbarra em consideração pessoais do professor, suas experiências, suas crenças, suas opiniões, suas disposições e recursos psicológicos para realizar tal trabalho. (FARIA et al., 2018). Desse modo, constata-se que o preparo emocional e psicológico dos profissionais para o novo trabalho que deles se exige também é relegado.

Sendo assim, educação inclusiva pode ser considerada plena apenas para uma realidade das leis, já que permanecem várias resistências à sua efetivação nas 
práticas e projetos institucionais. Dessa forma, "igualdade" da prática pedagógica serve como máscara e justificação para a indiferença no que diz respeito às desigualdades reais diante do ensino e da cultura transmitida. (BOURDIEU, 1998).

Gráfico 28 - Distribuição segundo a oferta de profissionais na escola

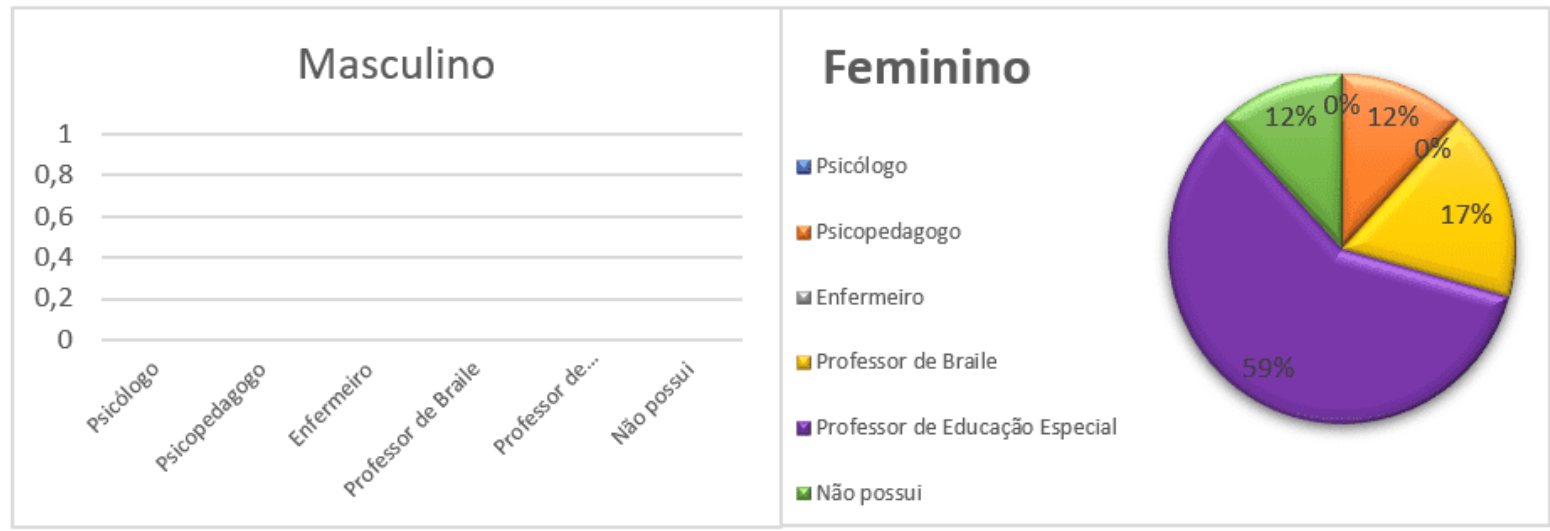

Fonte: Elaborado pelo autor (2020).

Segunda a oferta de profissionais na escola, observa-se que mais da metade (59\%) possui o profissional de educação especial para a formação do aluno especial, seguida do professor de braile (17\%) para deficientes visuais e, por último, psicopedagogo (12\%). Apesar das baixas taxas de profissionais qualificados no atendimento das necessidades especiais dos alunos, esse quadro está conforme o preconizado pela Lei 13.146 que estabelece formação e disponibilização de professores para o atendimento educacional especializado, de tradutores e intérpretes da Libras, de guias intérpretes e de profissionais de apoio. (BRASIL, 2015). Além disso, vale ressaltar a importância do envolvimento de todos os agentes que fazem parte do seu cotidiano do aluno especial - professores, outros alunos, coordenadores, diretores e funcionários - que estarão diretamente ligados à inclusão do aluno deficiente no ambiente educacional. (MARTINS, 2006). Sendo assim, os educadores devem estar ainda buscar recursos necessários para atender o aluno deficiente procurando atender suas necessidades através de meios especiais para orientação e apoio de que ele precisar no sentido de igualitariamente ter direito ao aprendizado. (BALSANELI et al., 2015). 
Gráfico 29 - Distribuição das atividades escolares voltadas para alunos especiais

\section{Masculino \\ - Acompanhamento escolar \\ $\square$ Reforço escolar \\ $\square$ Esportes \\ $\square$ Artes \\ $\square$ Apoio de estagiários \\ ๑ Psicomotricidade \\ - Outros (AEE)}

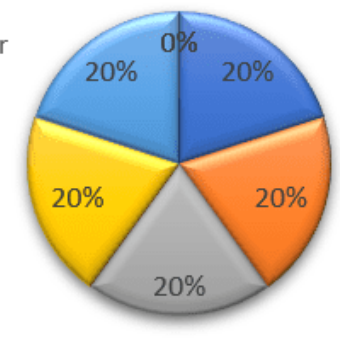

\section{Feminino}

Acompanhamento escolar

$\square$ Reforço escolar

घ Esportes

$\square$ Artes

\ Apoio de estagiários

\Psicomotricidade

- Outros (AEE)

Fonte: Elaborado pelo autor (2020).

Na distribuição das atividades escolares (Gráfico 29), nota-se que no sexo masculino as atividades são igualmente praticadas com exceção da psicomotricidade $(0 \%)$, já no sexo feminino revela-se maior prática de artes e reforço escolar (18\%), além de um maior contato com a área da psicomotricidade (11\%). Assim, como afirma Vygotsky (1989), é fundamental focar as potencialidades destes sujeitos, estimulado - o a explorar o mundo, a interagir com o outro, a expor sua opinião e desejos, sendo que as atividades lúdicas oferecem grandes oportunidades para isso. Assim, aumenta-se as possibilidades de aprendizagem do escolar com necessidades especiais, pois, através desses recursos, ele poderá vivenciar integralmente as situações de ensinoaprendizagem, desenvolvendo sua criatividade e expressividade, interagindo com outras pessoas, exercendo a cooperação e aprendendo em grupo. No Brasil, o documento que rege o processo de inclusão escolar é a Política Nacional de Educação Especial na perspectiva da Educação Inclusiva (2008), a qual tem como objetivo garantir inclusão escolar de alunos deficientes, com transtornos de desenvolvimento global e altas habilidades, a fim de lhes assegurar uma participação ativa, ao longo do processo de aprendizagem. (BRASIL, 2008). Ademais, a Lei Brasileira de Inclusão da Pessoa com Deficiência, assegura que a criança e o adolescente com quaisquer limitações têm direito, em igualdade condições, a jogos e a atividades recreativas, esportivas e de lazer, no sistema escolar, bem como à oferta de profissionais de apoio escolar para o acompanhamento individualizado e especializado. (BRASIL, 2015). 
Gráfico 30 - Distribuição dos recursos utilizados para a inclusão

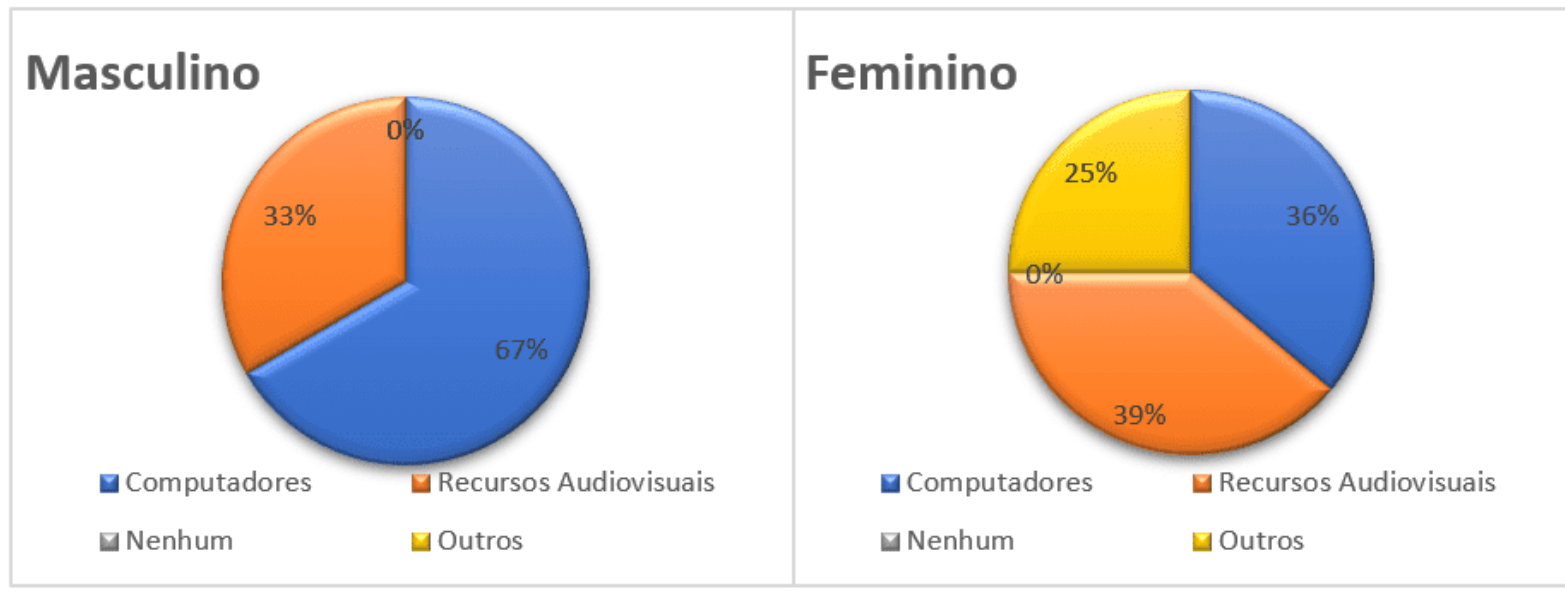

Fonte: Elaborado pelo autor (2020).

A partir da análise do gráfico distribuição dos recursos utilizados para inclusão dos alunos, fica evidente que prevalece o uso de computadores e recursos audiovisuais como forma de promover a inclusão na escola. Desse modo, a tecnologia assistida organiza e fortalece a linguagem, permitindo a comunicação efetiva e a aquisição de habilidades escolares e sociais, vitais para assegurar seu pleno desenvolvimento e autonomia, para realização de atividades tanto na escola quanto fora dela. Para tanto, se faz necessário a orientação e acompanhamento do aluno no momento da utilização dos recursos tecnológicos, com a intenção, de ajudá-lo na adaptação do mesmo. (HEIDRICH, 2003).

Gráfico 31 - Distribuição segundo as maiores dificuldades dos professores em trabalhar com alunos especiais.

Tendo em vista os dados do gráfico 31, nota-se que a maioria dos professores participantes relataram terem como principal desafio a falta de preparo profissional ( $67 \%$ no sexo masculino e $37 \%$ no feminino). Além disso, destacam-se dificuldades como ausência de materiais adequados, falta de equipe multidisciplinar, falta ou escassez de acompanhamento familiar, insegurança e inexistência de atendimento individualizado. 
No que tange à formação profissional, o cotidiano da sala de aula com educandos que tem algum tipo de deficiência requer do professor a capacitação para mediar as relações, mobilizar os conceitos e organizar os conteúdos estrategicamente, para que estes alunos se apropriem dos conhecimentos sistematizados e disponibilizados pela escola. (KONKEL et al., 2015). Somado a isso, a maioria dos professores tem uma visão funcional do ensino e tudo o que rompe com o esquema de trabalho prático que aprenderam e aplicam em suas salas de aula é inicialmente rejeitado. (MONTOAN, 2003). Logo, a presença de um aluno com necessidades especiais, não é vista como algo positivo, mas sim como um empecilho ao curso normal da sala, sendo necessário, portanto, mudanças também nas representações e concepções dos docentes.

Somado a isso, os elementos de ordem estrutural e organizacional das escolas, transformam-se em verdadeiros obstáculos aos professores, mesmo quando esses aceitam o desafio de educar a todos os alunos. Dessa forma, a escassez de recursos materiais, ausência de professores auxiliares, turmas numerosas e a multiplicidade de deficiências presentes em sala de aula são alguns dos fatores que impedem o avanço do processo de inclusão e aprendizagem plena. (DUEK, 2007). Nesse contexto, destaca-se a necessidade de classes menores, visto que os alunos especiais precisam de uma atenção direcionada e constante para conseguir o pleno desenvolvimento neuropsicossocial. Com isso, percebe-se que estamos imersos em uma estrutura educacional rudimentar e ultrapassada que se baseia em um único modo de lecionar, implicando que todos os alunos absorvam o conteúdo de forma unanime.

Mesmo os profissionais que encaram a renovação pedagógica no seu trabalho, ao perceberem a carência de recursos, veem-se divididos entre aquilo que fazem e o que gostariam de fazer em sua prática. Esse distanciamento entre o trabalho prático e 0 desejado se traduz na suspeição frente ao novo, o que gera sentimentos de inadequação e insegurança. (SOBRINHO, 2002).

Entretanto, a inclusão não se restringe ao ambiente escolar, ela requer engajamento e planejamento, extrapolando os limites da escola e chegando às famílias desses alunos e às instituições sociais em geral, fazendo-se necessário a orientação da 
comunidade escolar e o estabelecimento de um relacionamento efetivo entre a escola e a família. (MARTINS, 2003). Entende-se, portanto, que a inclusão da criança com necessidades educacionais especiais inicia muito antes de sua matrícula na escola, ainda no seio familiar. Cumpre à escola a função de encorajar a participação da família nas atividades educacionais, assumindo o lugar que the cabe de co-participante e coresponsável por esse processo.

\section{Terceiro Dia:}

No terceiro encontro, a ideia inicial era uma roda de conversa entre os professores da escola Prof. ${ }^{a}$ Maria Martins e Lourenço, alunos do $8^{\circ}$ Período do curso de pedagogia do Centro Universitário de Votuporanga e a diretora responsável pela APAE de Votuporanga. Entretanto, devido a carga horária e grade curricular dos discentes da faculdade, infelizmente, não houve a possibilidade da participação desses na reunião. Portanto, essa transcorreu apenas com os professores e a diretora da APAE.

Durante a discussão, foi abordado temas como a importância do preparo educacional para atender as demandas dos alunos com necessidades especiais, as diferentes formas de abordagem pedagógica para otimizar o aprendizado dessas crianças, os sinais de alerta e de necessidade de encaminhamento para centros educacionais especializados e os possíveis profissionais capazes de auxiliar o professor no processo de educação. No decorrer da reunião, os profissionais se mostraram muito interessados e realizaram perguntas pertinentes a cada assunto, além de acrescentarem relatos de experiência de seus cotidianos com alunos especiais,

Essa troca de conhecimento possui extrema importância para os professores, haja vista que o Censo Escolar de 2018 indicou a matricula de 1,2 milhão de portadores de necessidades especiais em escolas regulares no país, o que consiste em um aumento de $33,2 \%$ em relação a 2014. (INEP, 2018). Portanto, faz-se relevante que os profissionais da área conheçam os diferentes tipos de deficiência, além de esclarecerem suas dúvidas, a fim de potencializar as possibilidades de inclusão social e escolar. 


\section{CONCLUSÃO}

Conclui-se, portanto, que os objetivos desse trabalho foram atingidos, pois foi possível analisar as necessidades de aprendizagem dos professores e estagiários no processo de educação de crianças que possuem necessidades educacionais especiais.

Dentro da perspectiva da educação especial, o Brasil possui diversas leis e pautas que instituem a inclusão de crianças e adolescentes em condições diferenciadas como forma de abrangência para a inserção social destes. Entretanto, o presente projeto evidenciou que a inserção escolar de alunos com necessidades especiais vai além de cumprir políticas públicas e legislação, sendo de suma relevância a capacitação daqueles que atuam na área, a fim de proporcionar uma educação de qualidade e igualitária a todos e de romper os estigmas sociais sobre o assunto.

Dessa forma, faz-se necessário um trabalho conjunto entre as áreas da educação e da saúde, em que o primeiro promova uma educação de qualidade e apropriada de acordo com a demanda de cada aluno especial, objetivando e formação integral do indivíduo em toda a sua potencialidade; e o segundo realize um diagnóstico precoce e tratamento adequado de cada doença a fim de reduzir os impactos negativos no desenvolvimento da criança.

Somado a isso, é indispensável que as diversas esferas da educação no Governo (Ministério da Educação, Secretárias Estaduais da Educação e Secretárias Municipais da Educação) atuem promovendo aulas, cursos, formação social e profissional aos professores e estudantes em educação especial, além de debates acerca do tema, almejando ao fim dos estereótipos, medos e preconceitos para com esses alunos. Somente assim, a educação será mais do que igualitária, será equânime.

\section{REFERÊNCIAS}

AMARAL, Lígia Assumpção. Resgatando o passado: deficiência como figura e vida como fundo. São Paulo: Casa do Psicólogo, 2004. 
BALSANELI, Heloisa Monteiro; TREVISO, Vanessa Cristina. Crianças com deficiência visual e o braile. Cadernos de Educação: Ensino e Sociedade, Bebedouro, v.2, p. 155-168, 2015.

BLOS, Peter. Adolescência: Uma interpretação psicanalí

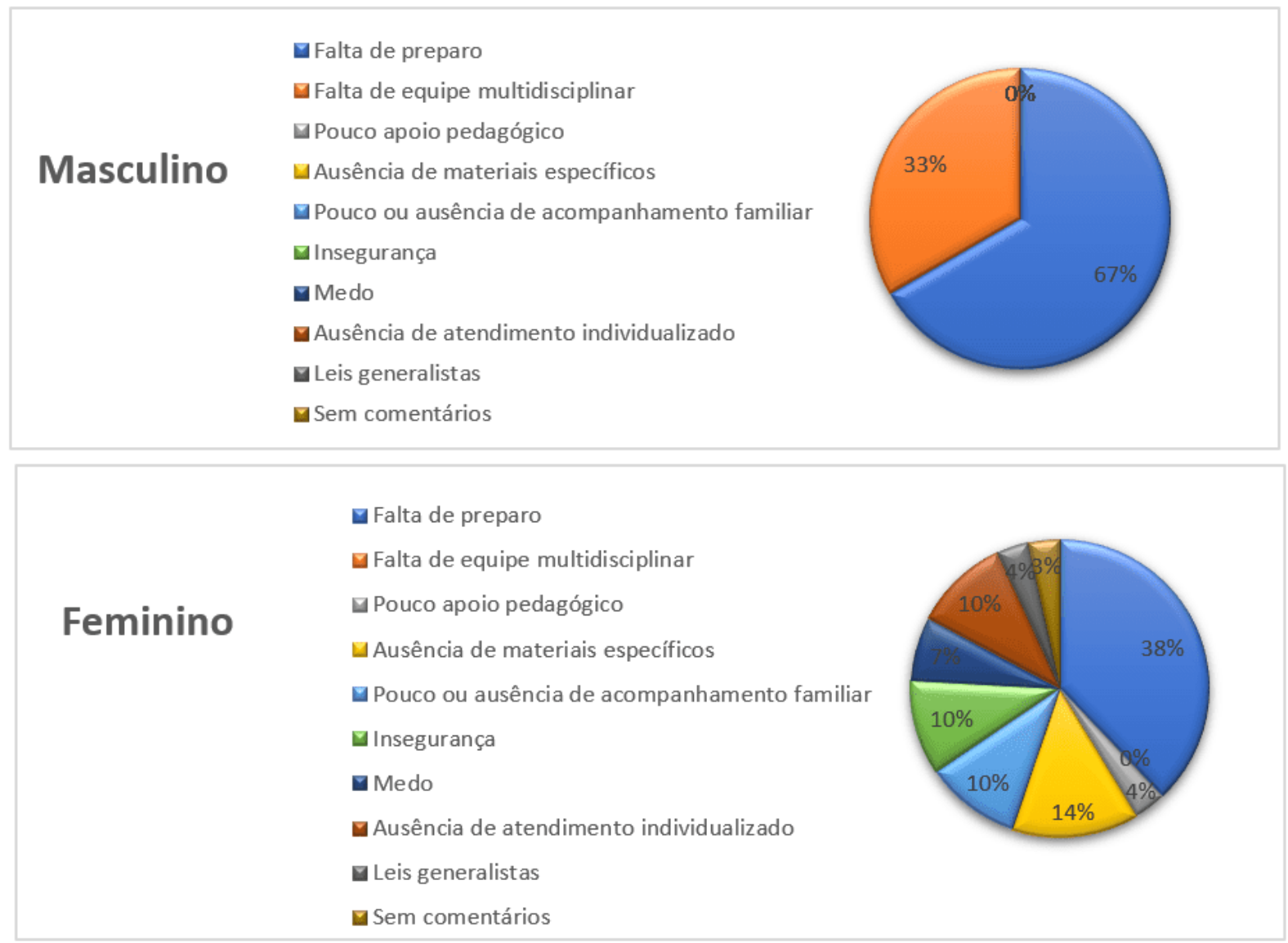

Fonte: Elaborado pelo autor (2020).

tica. São Paulo: Martins Fontes, 1998.

BOURDIEU, Pierre. A escola conservadora: as desigualdades frente à escola e à cultura. In: NOGUEIRA, Maria Alice.; CATANI, Alfredo. (Orgs.). Escritos de educação. Petrópolis: Vozes, 1998. p. 39-64.

BRASIL. [Constituição (1988)]. Constituição da República Federativa do Brasil de 1988. Brasília, DF: Presidência da República. Disponível em: 
http://www.planalto.gov.br/ccivil_03/constituicao/constituicaocompilado.htm. Acesso em: 30 out. 2019

BRASIL. Declaração de Salamanca e linha de ação sobre necessidades educativas especiais. Brasília: UNESCO, 1994.

BRASIL. Decreto no 1.130, de 05 de agosto de 2015. Institui a Política Nacional de Atenção Integral à Saúde da Criança (PNAISC) no âmbito do Sistema Único de Saúde (SUS). Brasília, DF: Ministério da Saúde, [2015]. Disponível em: http://bvsms.saude.gov.br/bvs/saudelegis/gm/2015/prt1130_05_08_2015.html. Acesso em: 14 out. 2019.

BRASIL. Decreto no 3. 298, de 20 de dezembro de 1999. Institui a Política Nacional para a Integração da Pessoa Portadora de Deficiência. Brasília, DF: Presidência da República, [1999].

Disponível em: http://www.planalto.gov.br/ccivil_03/decreto/D3298.htm. Acesso em: 30 out. 2019

BRASIL. Decreto no 6.286, de 5 de dezembro de 2007. Institui o Programa Saúde na Escola - PSE e dá outras providências. Brasília: Presidência da República, [2007]. Disponível em: http://portal.mec.gov.br/index.php?option=com_docman\&view=download\&alias=1726 -saudenaescola-decreto6286-pdf\&category_slug=documentos-pdf\&ltemid=30192. Acesso em: 16 out. 2019

BRASIL. Decreto no 7.611, de 17 de novembro de 2011. Dispõe sobre a educação especial, o atendimento educacional especializado e dá outras providências. Brasília, DF: Presidência da República, [2011]. Disponível em: http://www.planalto.gov.br/ccivil_03/_Ato2011-2014/2011/Decreto/D7611.htm. Acesso em: 16 out. 2019.

BRASIL. Lei no $\mathbf{8 0 8 0}$, de 19 de setembro de $\mathbf{1 9 9 0}$. Dispõe sobre as condições para a promoção, proteção e recuperação da saúde, a organização e o funcionamento dos serviços correspondentes e dá outras providências. Brasília, DF: Presidência da República, [1990]. Disponível em: https://bit.ly/332NgzQ. Acesso em: 30 out. 2019 
BRASIL. Lei no 9.394, de 20 de dezebro de 1996. Estabelece as diretrizes e bases da educação nacional. Brasília, DF: Presidência da República, [1996]. Disponível em: http://www.planalto.gov.br/ccivil_03/leis//9394.htm. Acesso em: 18 out. 2019

BRASIL. Lei $\mathbf{n}^{\circ}$ 12.796, de 04 de abril de 2013. Altera a Lei oㅜ 9.394, de 20 de dezembro de 1996, que estabelece as diretrizes e bases da educação nacional, para dispor sobre a formação dos profissionais da educação e dar outras providências. Brasília, DF: Presidência da República, [2013]. Disponível em: http://www.planalto.gov.br/ccivil_03/_ato2011-2014/2013/lei/12796.htm. Acesso em: 22 out. 2019

BRASIL. Lei no 13.146, de 06 de julho de 2015. Institui a Lei Brasileira de Inclusão da Pessoa com Deficiência (Estatuto da Pessoa com Deficiência). Brasília, DF: Presidência da República, [2015]. Disponível em: http://www.punf.uff.br/inclusao/images/leis/lei_13146.pdf. Acesso em: 26 out. 2019.

BRASIL. Ministério da Educação. Documento subsidiário à política de inclusão. Brasília: Secretaria de Educação Especial, [2005]. p. 48.

BRASIL. Ministério da Educação. Política Nacional de Educação Especial na Perspectiva da Educação Inclusiva. Brasília: MEC/SECADI, [2008]. Disponível em: https://bit.ly/2KtcEIP. Acesso em: 24 out. 2019.

BRASIL. Ministério da Educação. Saberes e práticas da inclusão. Dificuldades acentuadas de aprendizagem e deficiência múltipla. Brasília: Secretaria da Educação Especial, [2006]. Disponível em: http://portal.mec.gov.br/seesp/arquivos/pdf/deficienciamultipla.pdf. Acesso em: 18 out. 2019.

BUENO, José Geraldo Silveira. Crianças com necessidades educativas especiais, política educacional e a formação de professores: generalistas ou especialistas? Revista Brasileira de Educação Especial, Curitiba, v.3, n. 5, p. 7-25, 2009. 
CABRAL, Cristiane Soares; MARIN, Angela Helena. Inclusão escolar de crianças com transtorno do espectro autista: uma revisão sistemática da literatura. Educação em revista, Belo Horizonte, v.1, n. 33, p. 1-30, 2017. Disponível em: http://www.scielo.br/scielo.php?script=sci_arttext\&pid=S0102982017000100113\&lng =en\&nrm=iso Acesso em: 19 out. 2019

CURY, Carlos Roberto Jamil. Políticas inclusivas e compensatórias na educação básica. Caderno de Pesquisa, São Paulo, vol.35, n.124, p. 11-32, 2005.

DE LIMA, Tatiana. Processo de inclusão de alunos com transtorno de déficit de atenção e hiperatividade.In: ENCONTRO REGIONAL DE HISTÓRIA, XIV., 2014, Paraná. Anais... Paraná: Unespar, 2014. p. 2436 - 2448.

DUEK, Viviane Preichardt. Professores diante da inclusão: superando desafios. In: CONGRESSO BRASILEIRO MULTIDISCIPLINAR DE EDUCAÇÃO ESPECIAL, IV., 2007, Londrina. Anais... Londrina: UEL, 2007. p. 1-8. Disponível em: http://www.uel.br/eventos/congressomultidisciplinar/pages/arquivos/anais/2007/066.p df. Acesso em: 11 nov. 2019.

EDIER, Rosita. Removendo barreiras para aprendizagem: educação inclusiva. Porto Alegre: Mediação, 2000.

ESPANHA. Declaração de Salamanca sobre princípios, políticas e práticas na área das necessidades educativas especiais. Salamanca: 1994.

FARIA, Paula Maria Ferreira de; CAMARGO, Denise de. As Emoções do Professor Frente ao processo de Inclusão Escolar: uma Revisão Sistemática. Revista brasileira de educação especial, Bauru, v. 24, n. 2, p. 217-228, abr. 2018. Disponível em: https://www.scielo.br/scielo.php?script=sci_arttext\&pid=\$1413-65382018000200217. Acesso em: 30 out. 2019

FERRAIOLI, Suzannah.; HARRIS, Sandra. Effective educational inclusion of students on the autism spectrum. Journal of Contemporary Psychotherapy, v. 41, n. 1, p. 19-28, 2011. 
FERREIRA, Windyz. Educação Inclusiva: será que sou a favor ou contra uma escola de qualidade para todos? Revista da Educação Especial, Brasília, v. 2, n. 23, p. 4046, 2005.

FREITAS, Luiz. Carlos. A internalização da exclusão. Educação \& Sociedade, Campinas, v. 23, n. 80, p. 299-325, set. 2002.

GRAEFF, Rodrigo Linck; VAZ, Cícero. Avaliação e diagnóstico do transtorno de déficit de atenção e hiperatividade (TDAH). Psicologia USP, São Paulo, v. 19, n. 3, p. 341361 , set. 2008.

Disponível

em: http://www.scielo.br/scielo.php?script=sci_arttext\&pid=S010365642008000300005\&l ng=en\&nrm=iso. Acesso em: 17 out. 2019.

HEIDRICH, Regina de Oliveira; SANTAROSA, Lucila Costi. Novas tecnologias como apoio ao processo de inclusão escolar. CINTED-UFRGS, Rio Grande do Sul, v.1, n.1, p.1-10, 2003.2 Disponível em: https://seer.ufrgs.br/renote/article/download/13638/7717. Acesso em: 25 out. 2019

HONNEF, Cláucia. O desafio da formação docente frente à educação inclusiva. Revista Tempos e Espaços em Educação, São Cristóvão, v. 04, n. 6, p. 135-146, jan./jun. 2011.

IBGE - INSTITUTO BRASILEIRO DE GEOGRAFIA E ESTATÍSTICA. Pesquisa Nacional por Amostra de Domicílios: população residente, por sexo e grupos de idade, segundo as Grandes Regiões e as Unidades da Federação 2010. Rio de Janeiro. 2010.

Disponível

em: https://censo2010.ibge.gov.br/sinopse/index.php?dados=12. Acesso em: 12 out. 2019 INEP - INSTITUTO NACIONAL DE ESTUDOS E PESQUISAS EDUCACIONAIS ANÍSIO TEIXEIRA. Censo Escolar 2018 revela crescimento de 18\% nas matrículas em tempo integral no ensino médio. Brasília, DF. 2018. Disponível em: http://portal.inep.gov.br/artigo/-/asset publisher/b4aqv9zfy7bv/content/censo-escolar2018-revela-crescimento-de-18-nas-matriculas-em-tempo-integral-no-ensinomedio/21206. Acesso em: 29 out. 2019. 
KONKEL, Eliane Nilsen; ANDRADE, Cleudane; KOSVOSKI, Deysi Maia Clair. As dificuldades no processo de inclusão educacional no ensino regular: a visão dos professores do ensino fundamental. CONGRESSO NACIONAL DE EDUCAÇÃO, XII., Paraná, 2015. Anais... Paraná: Educere, 2015. p. 5776-5790. Disponível em: https://educere.bruc.com.br/arquivo/pdf2015/19144_8387.pdf. Acesso em: 30 out. 2019

LACERDA, Cristina Broglia Feitosa de. A inclusão escolar de alunos surdos: o que dizem alunos, professores e intérpretes sobre esta experiência. Cad. CEDES., Campinas, v. 26, n. 69, p. 163-184, 2006.

LOURO, Guacira Lopes. Gênero, sexualidade e educação: uma perspectiva pós estruturalista. Petrópolis: Vozes, 1997.

MANTOAN, Maria Teresa Eglér. Inclusão escolar: o que é? Porque é? Como fazer? São Paulo: Moderna, 2003.

MARTINS, Lúcia de Araújo Ramos. A inclusão escolar do portador da síndrome de Down: o que pensam os educadores? Natal: EDUFRN, 2003.

MARTINS, Lúcia de Araújo Ramos. Formação professores numa perspectiva inclusiva: algumas constatações. In: MANZINI, E.J. (Org) Inclusão e Acessibilidade. Marilia:

ABPPE, 2006.

Disponível em: http://seer.fclar.unesp.br/iberoamericana/article/viewFile/5375/4308. Acesso em: 27 out. 2019.

MAZZOTTA, Marcos José. Trabalho docente e formação de professores de educação especial. São Paulo: EPU, 1993.

MAZZOTTA, Marcos José. Educação especial no Brasil: história e políticas públicas. 5. ed.. São Paulo: Cortez, 2005

MELO, Francisco Ricardo Lins Vieira de; PEREIRA, Ana Paula Medeiros. Inclusão escolar do aluno com deficiência física: visão dos professores acerca da colaboração 
do fisioterapeuta. Revista brasileira de educação especial, Marília, v. 19, n. 1, p. 93106 , mar. 2013.

Disponível em:

http://www.scielo.br/scielo.php?script=sci_arttext\&pid=S1413-

65382013000100007\&lng=en\&nrm=iso. Acesso em: 15 out. 2019.

MITTLER, Petter. Educação inclusiva: contextos sociais. Porto Alegre: Artmed, 2003.

MONTILHA, Rita de Cassia letto et al. Percepções de escolares com deficiência visual em relação ao seu processo de escolarização. Paidéia, Ribeirão Preto, v. 19, n. 44, p. 333-339, dez. 2009. Disponível em: http://www.scielo.br/scielo.php?script=sci_arttext\&pid=S0103863X2009000300007\&Ing=en\&nrm=iso. Acesso em: 26 out. 2019.

NUNES SOBRINHO, Franciso de Paula. O stress do professor do ensino fundamental: o enfoque da ergonomia. In: LIPP, Marilda. (Org.). 0 stress do professor. Campinas: Papirus, 2002. p. 81-94.

NUNES, Sylvia da Silveira; SAIA, Ana Lucia; TAVARES, Rosana Elizete. Educação Inclusiva: Entre a História, os Preconceitos, a Escola e a Família. Psicologia: ciência e profissão, Brasília, v. 35, n. 4, p. 1106-1119, dez. 2015. Disponível em: http://www.scielo.br/scielo.php?script=sci_arttext\&pid=\$141498932015000401106\&l $\mathrm{ng}=\mathrm{en} \& \mathrm{nrm}=$ iso. Acesso em: 28 out. 2019

PASTURA, Giuseppe; MATTOS, Paulo; ARAÚJO, Alexandra. Prevalência do transtorno do déficit de atenção e hiperatividade e suas comorbidades em uma amostra de escolares. Arquivos de Neuro-Psiquiatria, São Paulo, v. 65, n. 4, p. 1078-1083, 2007.

Disponível em: http://www.scielo.br/scielo.php?script=sci_arttext\&pid=S0004282X2007000600033. Acesso em: 22 out. 2019

PLETSCH, Márcia Denise. A formação de professores para a educação inclusiva: legislação, diretrizes políticas e resultados de pesquisas. Educar em revista, Curitiba, n.33, p.143-156, 2009. 
http://www.scielo.br/scielo.php?script=sci_arttext\&pid=S010440602009000100010\&Ing=en\&nrm=iso. Acesso em: 26 out. 2019

SANCHES, Antonio Carlos Gonsales; OLIVEIRA, Márcia Aparecida Ferreira de. Educação inclusiva e alunos com transtorno mental: um desafio interdisciplinar. Psicologia: Teoria e Pesquisa, Brasília, v. 27, n. 4, p. 411-418, dez. 2011. Disponível em: http://www.scielo.br/scielo.php?script=sci_arttext\&pid=S010237722011000400004\&l $\mathrm{ng}=\mathrm{en \& nrm=iso.} \mathrm{Acesso} \mathrm{em:} 28$ out. 2019.

SANT'ANA, Izabella Mendes. Educação inclusiva: concepções de professores e diretores. Psicologia em Estudo, Maringá, v. 10, n. 2, p. 411-418, mai/ago. 2005.

SANTOS, Daísy Cléia Oliveira dos. Potenciais dificuldades e facilidades na educação de alunos com deficiência intelectual. Educação e Pesquisa, São Paulo, v. 38, n. 4, p. 935-948, dez. 2012.2 Disponível em: http://www.scielo.br/scielo.php?script=sci_arttext\&pid=S1517970220120004000 $10 \& \operatorname{lng}=$ en\&nrm=iso. Acesso em: 19 out. 2019

SKINNER. B. F. (1972). Tecnologia do Ensino. Tradução organizada por R. Azzi. São Paulo: EPU (trabalho original publicado em 1957).

SKLIAR, C. Educação e exclusão: abordagem sócio-antropológicas em educação especial. Porto Alegre: Mediação, 1997.

SOUSA, Priscila Batista de; SÁ-LIMA, Mariana Araguaia de Castro; VALVERDE, Clodoaldo. A inclusão escolar de alunos com Síndrome de Down na última década. Pedagogia em Foco, Iturama, v. 12, n. 8, p. 44-60, jul./dez. 2017. Disponível em: https://revista.facfama.edu.br/index.php/PedF/article/view/316/. Acesso em: 13 out. 2019.

THESING, Maria Luzia; COSTAS, Fabiane Adela. As proposições de uma escola inclusiva na concepção de professores de educação especial: algumas problematizações. Revista Brasileira de Estudos Pedagógicos, Brasília, v. 99, n. 
252

p. 277-293,

ago.

2018.

Disponível

em:

http://www.scielo.br/scielo.php?script=sci_arttext\&pid=S217666812018000200277\&l ng=en\&nrm=iso\&tlng=pt. Acesso em: 25 out. 2019.

VIANNA, Cláudia. Contribuições do conceito de gênero para a análise da feminização do magistério no Brasil. In: CAMPOS, Maria Christina Siqueira de Souza; SILVA, Vera Lúcia (orgs.) Feminização do magistério: vestígios do passado que marcam o presente. Bragança Paulista: Edusf, 2002. p.39-67.

VYGOTSKY, Marta Kohl de. Aprendizado e desenvolvimento: um processo sócio histórico. São Paulo: Scipione, 1993.

\section{APÊNDICE}

\section{APÊNDICE A - Questionário para Estagiários do Curso de Pedagogia da UNIFEV e para Professores da Escola Municipal Pesquisada}

Qual sua idade?

Sexo: Feminino Masculino

- A escola onde você atua possui alunos especiais?

$\operatorname{Sim}$

Não

Caso tenha, qual o perfil desse aluno com necessidades especiais?

Visual

Física

Auditiva

Psiquiatra

Hiperatividade 
Síndrome

Outras patologias. Qual(is)?

- Você já teve a oportunidade de se preparar para a educação especial através de atividades curriculares ou extracurriculares? (Especificar se foi oferecido pela instituição)

Sim Não

- Você já teve a oportunidade de trabalhar com um aluno especial? Se sim, quais as dificuldades encontradas em promover atividades educacionais?

Sim

Não

- A escola que você atua, é adaptada para receber os alunos especiais?

$\operatorname{Sim}$

Não

- Caso a resposta da pergunta acima seja não, o que deveria ser incrementado? (é possível assinalar mais de uma opção)

Rampas

Barras de apoio

Corredores mais largos

Banheiros adaptados

Salas amplas

Professor auxiliar

Material didático específico

Professor especializado em libras

Outros: 
- Você encontra resistência por parte de outros profissionais da educação em trabalhar com alunos especiais?

$\operatorname{Sim}$

Não

- Caso a resposta da pergunta acima seja sim, quais são os tipos de resistência que você considera existir? (É possível assinalar mais de uma opção)

Medo

Preconceito

Falta de oportunidade de preparo

Falta de interesse

Falta de empatia

Preguiça

Outros:

- Na escola que você atua, tem profissional especializado como:
Psicólogo
Psico-pedagogo
Enfermeiro

Outros:

- Quais atividades são realizadas na escola onde atua?

Acompanhamento pedagógico

Reforço escolar

Artes

Esportes

Apoio de estagiários

Psicomotricidade

Outros:

10- Quais recursos são utilizados para inclusão? 
Outros:

11- Comente sobre as maiores dificuldades encontradas para trabalhar com aluno

Enviado: Setembro, 2020.

Aprovado: Novembro, 2020. 